\title{
Late Ediacaran lateral-escape tectonics as recorded by the Patos shear zone (Borborema Province, NE Brazil)
}

\author{
Carlos José Archanjo 1* (D, Maria Helena Bezerra Maia de Hollanda' (D, Luis Gustavo Ferreira Viegas² (D)
}

\begin{abstract}
Lateral escape tectonics mediated by strike-slip fault zones are an efficient mechanism of rock deformation in the continental crust of collision zones. The Borborema shear zone system, which shows dimensions comparable to the Cenozoic extrusion of Indochina, defines a lateral escape setting of the Brasilano orogeny in Northeastern Brazil. In this paper, the timing of high-grade metamorphism and compositions of the terranes involved in the shear deformation were investigated. The Patos shear corridor deforms the Siderian to Neoarchean rocks of the Granjeiro Complex that, in turn, form the basement of Seridó-Lavras da Mangabeira metapelites. U-Pb zircon ages and Sm-Nd whole-rock isotopic compositions indicate that the $2.80-2.35$ Ga basement sequences mainly include juvenile material, whereas zircons from synkinematic migmatites indicate that the partial melting occurred in the Late Ediacaran (ca. $565 \mathrm{Ma}$ ). Cooling rates provided by ${ }^{40} \mathrm{Ar} /{ }^{39} \mathrm{Ar}$ range from 12 to $17^{\circ} \mathrm{C} / \mathrm{Ma}$, indicating a differential shear zone exhumation, in agreement with a transpressive setting. The presence of allochthonous Siderian sequences dismembered along the shear zone suggests that the Seridó-Granjeiro corridor defines a major tectonic boundary connected to the collisional front defined by the convergence of São Francisco-Congo and Amazonian cratons.
\end{abstract}

KEYWORDS: shear zone; geochronology; tectonics; Borborema Province; Brazil.

\section{INTRODUCTION}

Continental strike-slip faults are important components to understand the evolution of orogenic belts as they are often formed at plate margins, particularly along conservative and convergent settings (Woodcock and Schubert 1994). The convergence between India and Eurasia in the Cenozoic is a worldwide reference frame in that major thrust faults form in the leading edge of the subducting India slab, whereas strike-slip faults develop laterally to provide space for the India plate to move North into the paleomargin of the Eurasian plate (Tapponnier et al. 1982, Klemperer 2006). This indentation tectonic model would result in the extrusion to the Southeast of Indochina (Sundaland block; Fig. 1A), with the strike-slip faults accommodating the lateral escape. Another frame of reference for continental extrusion tectonics is the seismically active North Anatolian strike-slip fault that accommodates the lateral escape of the Anatolian plate sandwiched between the Arabian and

\footnotetext{
Supplementary Data

Supplementary data associated with this article can be found in the online version: Supplementary Table A and Supplementary Table B.

${ }^{1}$ Instituto de Geociências, Universidade de São Paulo - São Paulo (SP), Brazil.E-mails: archan@usp.br, hollanda@usp.br

${ }^{2}$ Instituto de Geociências, Universidade de Brasília - Brasília (DF), Brazil. E-mail: lgviegas@unb.br

${ }^{*}$ Corresponding author.
}

(c) 2021 The authors. This is an open access article distributed under the terms of the Creative Commons license.
Eurasia plates (Sengor et al. 2005). Recent discussions about the extrusion tectonics concern the timing of the strike-slip motion, the magnitude of the geological offset and the strain location processes, the depth of faulting and the relationship between magmatism and shear deformation (Vauchez and Tommasi 2003, Molnar and Dayem 2010, Searle et al. 2010, Norris and Toy 2014, Liu et al. 2020).

The Neoproterozoic strike-slip system of the Northeastern Brazilian Platform formed by the Transbrasiliano Lineament (TBL) and the Borborema Province shear zones is comparable in length to the Himalayan faults formed in the Cenozoic (Fig. 1). Gravimetric and magnetometric data indicate the Borborema shear zones merge with the TBL underneath the Parnaíba basin (Castro et al. 2014, Oliveira and Medeiros 2018), implying that they can reach a thousand kilometers in length in Northeast Brazil. Such a major fault system occurs between the São Francisco-Congo and the Amazonian-West African cratons that converged in the Ediacaran to assemble the West Gondwana (Merdith et al. 2017). It has long been recognized that the fault system would have facilitated the lateral escape of the Borborema terranes (Caby 1989), with the shear zone kinematics and associated magmatism investigated by Corsini et al. (1991), Vauchez and Egydio da Silva (1992), Tommasi et al. (1995), Neves et al. (1996), Archanjo et al. (2002), Weinberg et al. (2004), among others. An integrated model for extruding the Borborema terranes has been recently proposed by Ganade de Araújo et al. (2013), who attributed to the Transbrasiliano lineament a dextral transform fault that would approach the Amazonian-West African 


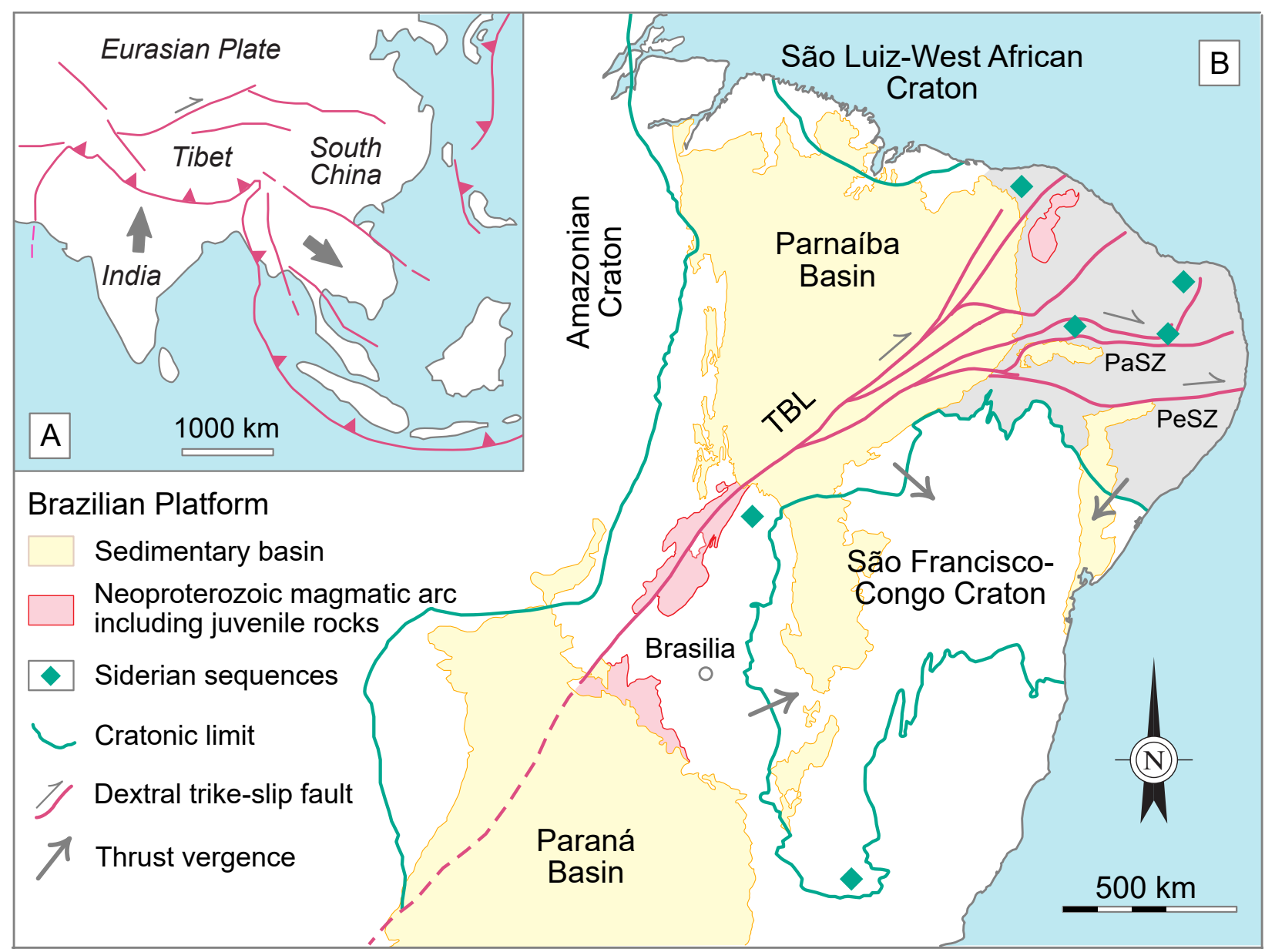

Figure 1. (A) Schematic tectonic map of the India-Eurasia collision showing the extrusion of Indochina and (B) main structures of Brazilian Platform highlighting major continental shear zones such as the Transbrasiliano Lineament (TBL), Patos (PaSZ) and Pernambuco (PeSZ) shear zones (modified from Cordani et al. 2016). The Transbrasiliano Lineament was traced in the Borborema Province (shaded area) according to Daly et al. (2014).

and São Francisco-Congo cratons to squeeze and rotate the Borborema Province. Paleomagnetic results, in contrast, suggest an independent evolution for the Amazonian craton, which would have detached from the Rodinia paleocontinent to collide with the São Francisco craton in the Early-Mid Cambrian (Tohver et al. 2010).

This paper investigates the timing of high-grade metamorphism and exhumation of the Patos shear zone (Fig. 1B), as well as the terranes involved in shear deformation. Geophysical evidence indicates that the Patos shear corridor constitutes a major tectonic boundary that limits crustal domains with different geological evolutions (Lima et al. 2015, Padilha et al. 2017, Oliveira and Medeiros 2018). Based on zircon $\mathrm{U}-\mathrm{Pb}$ (SHRIMP) ages from syn-kinematic migmatites, the Late Ediacaran metamorphism and evidence of the involvement of Neoarchean to Rhyacian basement sequences in the development of the high-grade mylonites are confirmed. In turn, ${ }^{40} \mathrm{Ar} /{ }^{39} \mathrm{Ar}$ determinations show that the exhumation of the shear zone was heterogeneous, with cooling phases extending to the Cambrian. The Siderian units occur as dismembered slices along the Patos shear zone and the Seridó belt, which suggests the mylonites would define a terrane boundary that extends to Central Brazil. These new data are consistent with lateral escape tectonics that resulted from the westward (modern geographic coordinates) convergence of the São Francisco plate.

\section{GEOLOGICAL SETTING}

Major shear zones divide the Borborema into three main domains: the Northern domain, separated from the central domain by the Patos shear zone; and the central domain (the Transversal Zone) separated from the Southern domain by the Pernambuco shear zone (Fig. 2). Farther South, the São Francisco craton marks the limit of the province. This study is focused on the Western sector of the Patos shear zone, which includes the Lavras da Mangabeira strike-slip duplex and rocks of the Granjeiro Complex (Silva et al. 1997).

The basement of the Northern Borborema domain consists largely of Rhyacian $(2.2-2.1 \mathrm{Ga})$ gneisses and migmatites including Archean fragments locally (Dantas et al. 2013, Costa et al. 2018, Ferreira et al. 2020). This basement also contains minor Orosirian metavolcano-sedimentary sequences and plutons (Sá et al. 1995, Hollanda et al.2011, Sá et al.2014), as well as local Siderian rocks situated next to the Transbrasiliano Lineament (Santos et al. 2009; Fig. 1B) and in the Seridó belt (Hollanda et al. 2011, Ferreira et al. 2019; Fig. 2). The Neoproterozoic metasedimentary belts rest unconformably on top of the 


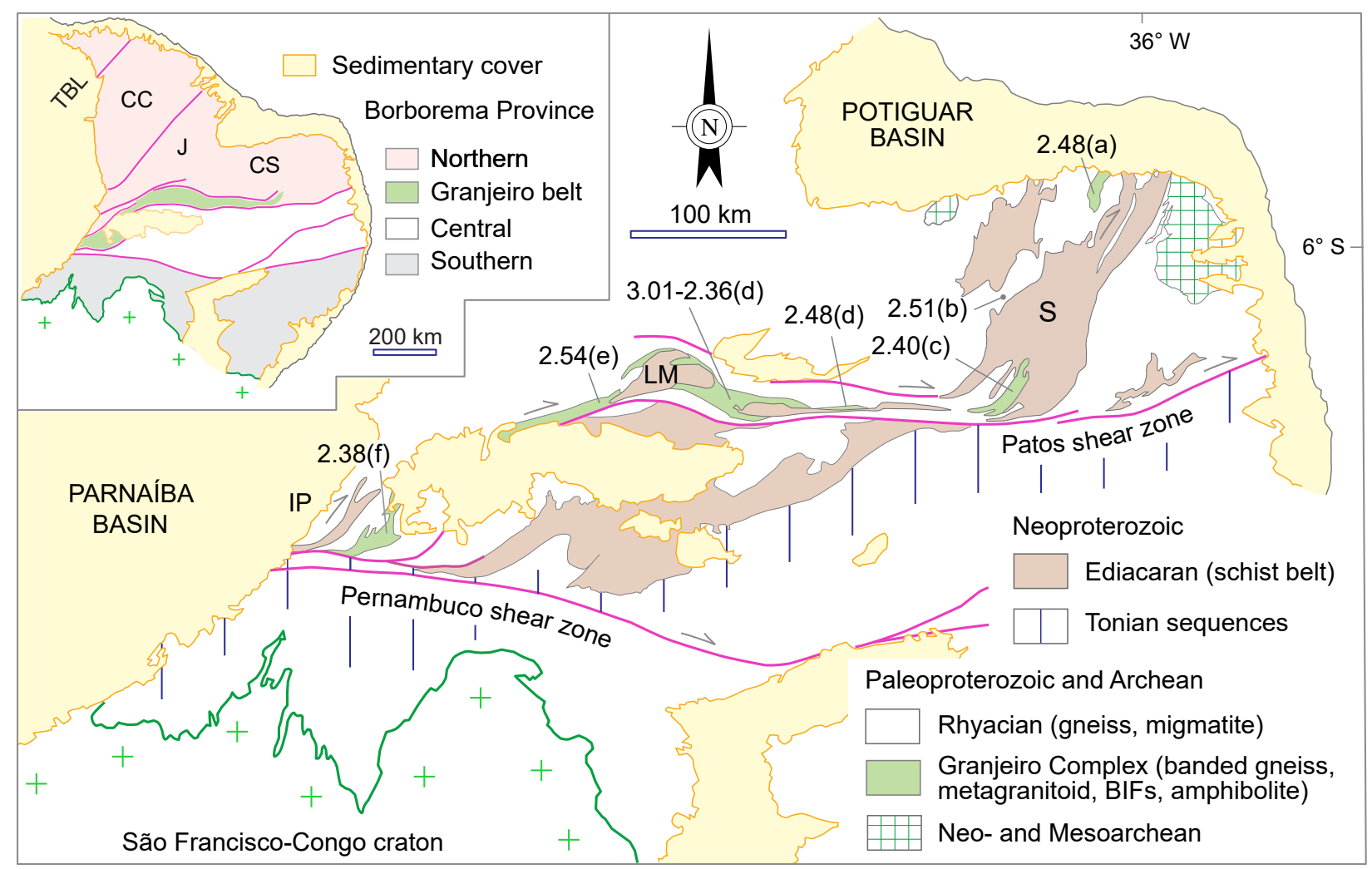

TBL: Transbrasiliano Lineament.

Figure 2. Borborema Province (inset) showing the distribution of Archean and Siderian rocks along the Seridó (S), Lavras da Mangabeira (LM) and Ipueirunha (Ip) belts. Ages (in Ga) in the Granjeiro Complex from (a) Ferreira et al. (2019), (b) Cavalcante et al. (2016), (c) Hollanda et al. (2011), (d) this study, (e) Silva et al. (1997) and (f) Pitarello et al. (2019). The Patos shear zones divide the province into the Central and Northern domains, the latter comprising the Caicó-Seridó (CS), Jaguaribeano (J) and Ceará Central (CC) subdomains.

older basement, such as the Lavras da Mangabeira and Seridó sequences. Based on detrital zircons and Nd isotopic compositions, the Seridó, Lavras da Mangabeira and Ipueirinha pelites derive from a synorogenic turbidite setting (Jardim de Sá 1994, Caby et al. 1995) with the youngest detrital zircons dated at ca. $630 \mathrm{Ma}$ (Van Schmus et al. 2003, Hollanda et al. 2015, Basto et al. 2019). There is no evidence that these Neoproterozoic basins were floored by oceanic crust; instead, the available data suggest that these basins were deposited on a sialic basement (Van Schmus et al. 2003, Hollanda et al. 2015).

The Central Borborema domain, situated between the Patos and Pernambuco shear zones, mostly consists of basement rocks of Rhyacian age including local Calymmian (ca. $1.6 \mathrm{Ga}$ ) alkaline plutons, and Tonian (ca. 1.0 Ga) orthogneisses and metavolcaniclastic sequences (Sá et al. 2002, Santos et al. 2010, Lages et al. 2019). Whereas the Calymmian magmatism has been attributed to an extensional Mesoproterozoic event, the tectonic setting of the Tonian sequences has been attributed to a continental rifting (Neves 2003, Guimarães et al. 2016) or an accretionary orogenic system (Santos et al. 2010, Caxito et al.2014, Lages and Dantas 2016, Caxito et al. 2020). Tonian rocks, in contrast, are not recorded in the Northern Borborema domain, which suggests that the Patos shear zone joins large crustal blocks with different geological evolution. The Southern Borborema domain comprises metasedimentary belts (Riacho do Pontal and Sergipano) thrust over the São Francisco craton (Davison and Santos 1989, Oliveira et al.
2010, Caxito et al. 2014). As the high-grade basement gneisses and migmatites of the central and Southern Borborema include Tonian sequences, these domains would share a similar tectonic evolution.

\section{THE PATOS MYLONITE BELT AND GRANJEIRO COMPLEX}

The Patos shear zone is an important tectonic corridor mostly consisting of E- to NE-trending mylonites and migmatites. The E-trending central segment consists of gneissic mylonites, metatexites and diatexites that can be traced in structural and geophysical continuity to the NE-trending Seridó belt (Corsini et al. 1991, Domingos et al. 2020), whereas to the West these rocks form imbricated slices that define the Lavras da Mangabeira strike-slip duplex. Available U-Pb zircon ages for the basement rocks situated between the Patos and Seridó belts are Siderian to Rhyacian (Hollanda et al. 2011, Viegas et al. 2014), whereas the metasedimentary units disrupted along the E-trending shear zone branch were deposited in the Neoproterozoic (Hollanda et al. 2015). In addition, distinct rock slices involved in the duplex structure yield Neoarchean ages to define the Granjeiro Complex (Silva et al. 1997).

The Granjeiro Complex consists of tonalitic and granodioritic gneisses, mafic and ultramafic rocks including lenses of metasedimentary rocks such as marble, BIFs and metacherts (Silva et al. 1997). The banded gneisses (Fig. 3A) are 
characterized by alternating $\mathrm{cm}$ - to dm-thick layers of felsic and intermediate to mafic rocks, including local ultramafic lenses. These units are usually migmatized as attested by shear zone-parallel leucosomes (Fig. 3B), some of them defining asymmetric boudins typical of dextral movement (Fig. 3C). Calc-silicate and mafic enclaves, a few having been rotated, locally fractured and infilled by felsic leucosomes (Fig. 3D) can be found included in a mesosome of granitic composition. These enclaves possibly correspond to "restitic material" left after a high-degree of partial melting of the host rocks.

The deformation of the Granjeiro rocks involved in the Lavras da Mangabeira duplex was described by Corsini et al. (1996). The transition from the E-W to the NE-SW structural trend is characterized by an arcuate array of anastomosing shear zones. The imbricate sequences usually consist of unmylonitized rocks in the cores of the slices wrapped around by shear zones with a sigmoidal trace typical of dextral shearing. The mylonitic foliation is consistently steeply dipping but, towards the cores of the slices, low- and high-angle foliations coexist suggesting a complex deformation regime. In the arcuate structure, however, the foliation and strike-slip shear zones define an asymmetric flower structure with the dip of foliation decreasing gradually from South to North (Corsini et al. 1996). In contrast, the stretching lineation is normally subhorizontal, regardless of the foliation dip.

\section{SAMPLING AND ANALYTICAL PROCEDURES}

The samples used for U-Pb analysis in zircon, whole-rock $\mathrm{Sm} / \mathrm{Nd}$ and ${ }^{40} \mathrm{Ar} /{ }^{39} \mathrm{Ar}$ in amphibole and biotite are indicated in Figure 4. All analytical procedures, including mechanical preparation and mineral concentration, optical imaging and isotopic determinations were conducted by Centro de Pesquisas Geocronológicas e Isotópicas (CPGeo) of Universidade de São Paulo.

The procedures used in zircon analysis follow the standard techniques that are commonly used for mineral dissociation from rocks, such as jaw crushing, sieving and separation by hydraulic, magnetic and density procedures. Approximately fifty zircons were picked off the concentrates, mounted and polished on resin discs. The mounts were imaged by cathodoluminescence $(\mathrm{CL})$ and the transmitted light was used to enhance the zircon internal structures such as growth zoning, inherited cores, recrystallized or metamictized sites, microfractures and inclusions.

The CL images were obtained using a CENTAURUS detector coupled to a Quanta 250 FEY scanning electron microscope. After imaging, the zircon U-Th-Pb isotope compositions were determined using a SHRIMP IIe instrument (see Sato et al. 2014 for further details). The data were collected in sets of five scans of the masses, and the analytical reliability was tested by analyzing the Temora standard after every third
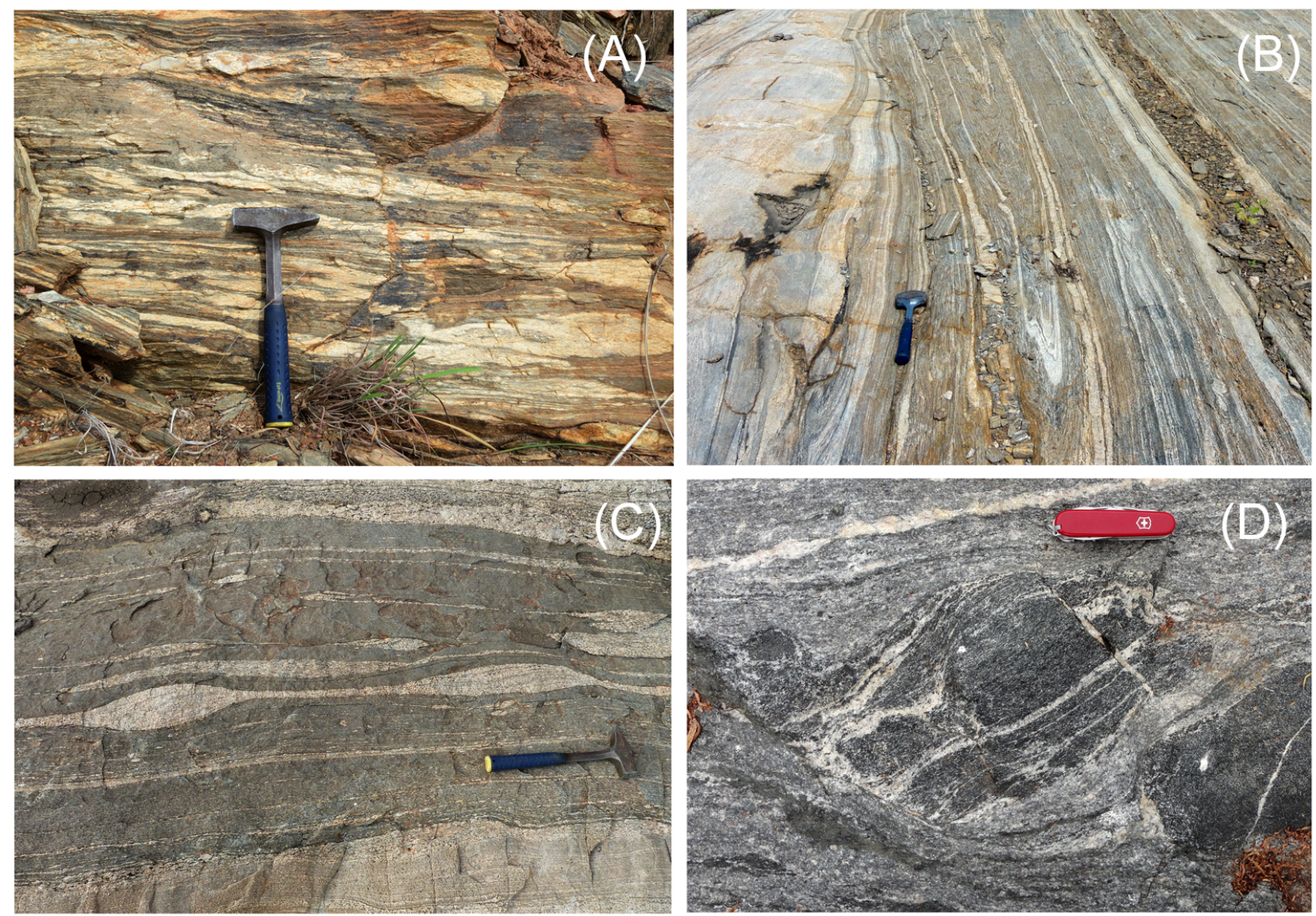

Figure 3. (A) Banded gneiss of the Granjeiro Complex that consists of alternating dark dioritic and light granitic layers (LM33). (B) Migmatite including folded granitic leucosomes hosted in a gray granitic mesossome with biotite and hornblende (COR2). (C) Asymmetric boudinaged leucosomes in diatexite indicating dextral shear movement (CIPA). (D) Amphibolite clot invaded by granitic leucosomes, both enclosed in a gray mesosome of granitic composition (CAJ3) (see Figure 4 for location). 


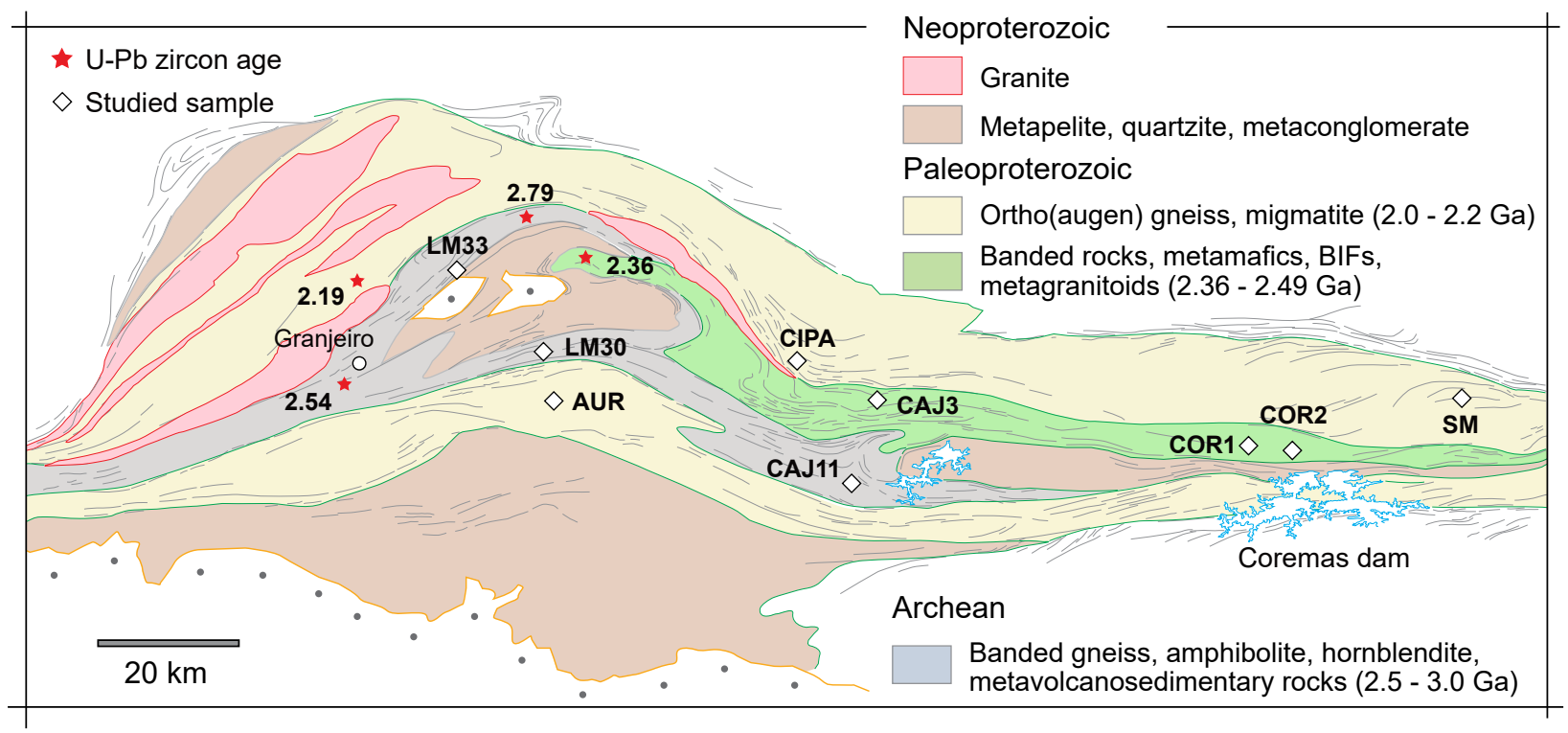

Figure 4. Patos shear zone showing the distributions of Archean, Siderian and Rhyacian rocks and the samples collected in this study. Stars: published ages after Silva et al. (1997), Bautista (2012) and Hollanda et al. (2015) (see text).

unknown analysis. The abundances of $\mathrm{U}$, Th and $\mathrm{Pb}$, as well as $\mathrm{Pb}$ isotope ratios were normalized using the SL13 zircon standard $(\mathrm{U}=238 \mathrm{ppm})$. Common $\mathrm{Pb}$ was corrected using measured ${ }^{204} \mathrm{~Pb}$ and assuming the $\mathrm{Pb}$ composition model of Stacey and Kramers (1975). Data reduction was performed using the SQUID/Excel macro (Ludwig 2000) and statistical assessments were calculated using ISOPLOT/Excel 3.0 software of Ludwig (2003). The U-Pb results are presented in Supplementary Table A.

Whole-rock Sm and Nd concentrations and isotopic compositions were measured with a Triton-Thermo Fisher Scientific mass spectrometer and data were acquired through multi-collector static mode using an array of 8 Faraday cups. ${ }^{143} \mathrm{Nd} /{ }^{144} \mathrm{Nd}$ and ${ }^{147} \mathrm{Sm} /{ }^{144} \mathrm{Nd}$ ratios have quoted errors are $2 \sigma$ and $1 \sigma$ levels, respectively. The JNDi- 1 standard yielded an average ${ }^{143} \mathrm{Nd} /{ }^{144} \mathrm{Nd}$ ratio of $0.512100 \pm 9(1 \sigma)$ during the period of the analyses. The measured $\mathrm{Nd}$ isotopic ratios were calibrated to the La Jolla standard $\left({ }^{146} \mathrm{Nd} /{ }^{144} \mathrm{Nd}=0.7219\right)$ and ${ }^{143} \mathrm{Nd} /{ }^{144} \mathrm{Nd}=\mathrm{Nd}(\mathrm{CHUR})_{0}=0.512638$ and ${ }^{147} \mathrm{Sm} /{ }^{144} \mathrm{Nd}$ $=0.1967$. The data were corrected for instrumental bias, tracer content and from blanks of 40pg (Nd) and $20 \mathrm{pg}(\mathrm{Sm})$ (Petronilho 2009). Sm-Nd $\mathrm{T}_{\mathrm{DM}}$ model ages were calculated according to DePaolo (1981), whereas $\varepsilon_{\mathrm{Nd}(\mathrm{t})}$ values are referred to the $\mathrm{U}-\mathrm{Pb}$ crystallization ages.

For ${ }^{40} \mathrm{Ar} /{ }^{39} \mathrm{Ar}$ determination, the mineral separates (hornblende and biotite) were irradiated with the Fish Canyon sanidine in the TRIGA nuclear reactor at the Oregon State University. Ar isotope compositions of irradiated samples were determined using the Thermo Scientific Model Argus VI mass spectrometer. Gas extraction and purification were performed using a Nd: $\mathrm{YVO}_{4}$ laser connected to an ultra-high vacuum cleanup line (SAES-GP-50). Data reduction, including correction for nuclear and background interferences, mass discrimination, J-value determination and graphical representation was applied using the ArArCALC v2.6.e software package
(Koppers 2002). Ratios of ${ }^{40} \mathrm{Ar} /{ }^{39} \mathrm{Ar}$ were measured in relation to the flux monitor standard Fish Canyon $(28.01 \pm 0.04 \mathrm{Ma}$; Phillips and Matchan 2013). Plateau ages (reported at $\pm 2 \sigma$ level uncertainty) are the weighted (by inverse variance) means of at least three sequential and concordant step ages that include $\geq 50 \%$ of ${ }^{39} \mathrm{Ar}$ released. The $40 \mathrm{Ar} / 39 \mathrm{Ar}$ results for the 8 samples are summarized in Supplementary Table B.

\section{RESULTS}

\section{Zircon U-Pb}

Three samples of banded gneiss (CAJ11, LM30 and LM33), four samples of orthogneiss (COR 1, COR2, AUR and SM) and two samples of diatexite (CAJ3 and CIPA; see location in Figure 4) were analyzed. Intercept ages are calculated at $1 \sigma$ level and the average ${ }^{207} \mathrm{~Pb} /{ }^{206} \mathrm{~Pb}$ or ${ }^{206} \mathrm{~Pb} /{ }^{238} \mathrm{U}$ ages are quoted at $95 \%$ confidence.

Two samples of banded gneisses provided the Archean ages. Sixteen zircons from a tonalitic gneiss with biotite and hornblende (CAJ11) show discordant ages between 3011 Ma and $2086 \mathrm{Ma}$ (Suppl. Tab. A). Zircons are subhedral to anhedral with aspect ratios between 1.5:1 and 2:1, and lengths ranging from 100 to $250 \mu \mathrm{m}$. Most zircons have oscillatory zoning that is interpreted as the result of magmatic growth, but recently developed U-poor rims around magmatic cores suggest a metamorphic event. The spots are focused on the oscillatory zoning sectors and in three grains (spots \#2, \#10 and \#15), in both cores and low-U rims. The Th/U ratios of the analyzed grains range from 0.30 to 1.01 , i.e., higher than $\mathrm{Th} / \mathrm{U}$ $<0.1$ admitted for metamorphic zircons (Rubatto 2002). Eleven analyses that cluster next to the concordia provided an upper intercept age of $3020 \pm 48 \mathrm{Ma}$ (MSWD, 2.5; Fig. 5), which can be considered the best estimate of the crystallization age for this sample. By including the analyses of the rims 

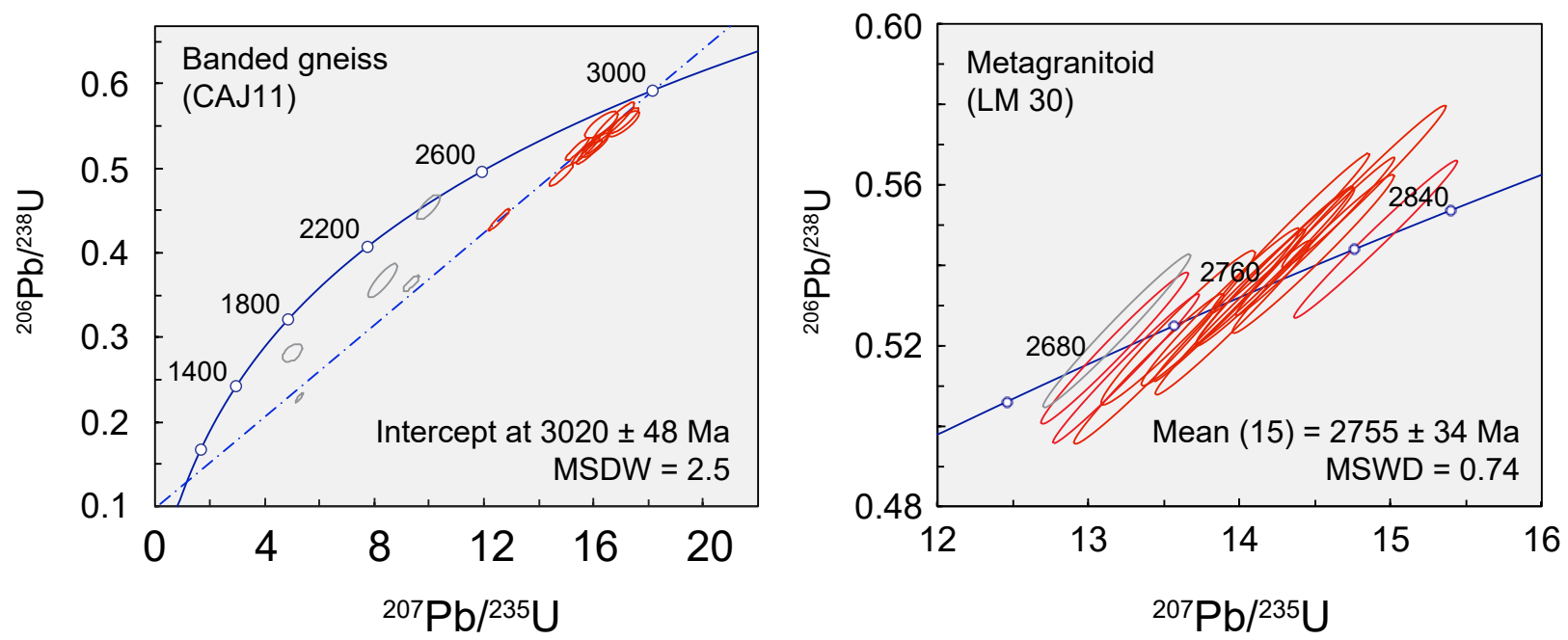

Figure 5. Archean zircon U-Pb ages of the Granjeiro Complex (see Figure 4) for further details/location.

and most discordant zircons the discordia line yields a lower intercept of ca. $1200 \mathrm{Ma}$ (MSWD, 28), with no apparent geological significance.

Sixteen zircons of the sample LM30 come from the dark, mafic layer of banded gneiss. The rock consists of an equigranular quartz-diorite with foliation defined by biotite and brown amphibole. The analyzed zircons, between 100 and $300 \mu \mathrm{m}$ in length, show $\mathrm{Th} / \mathrm{U}$ ratios in the range between 0.84 and 3.01. The spots, located on the concentric zoned sectors, are distributed in the concordia curve between 2.68 and $2.80 \mathrm{Ga}$ (Fig. 5), although a group of eleven zircons ranges between 2.73 and $2.76 \mathrm{Ga}$. If one zircon with high ${ }^{204} \mathrm{~Pb}(\# 4)$ is discarded, the remaining fifteen analyses yield a mean ${ }^{207} \mathrm{~Pb} /{ }^{206} \mathrm{~Pb}$ age of $2755 \pm 34 \mathrm{Ma}$ (MSWD, 0.74). This sample provides a $\mathrm{Nd}$ model age of $3.21 \mathrm{Ga}$ and a positive $\varepsilon_{\mathrm{Nd}}$ assuming that the rock crystallized at $2.8 \mathrm{Ga}$ (Tab. 1 ).

A gray orthogneiss (LM33) and two migmatitic gneiss (COR1 and COR2; see Figs. 6A-6C) evidenced Siderian ages. Fifteen euhedral to subhedral zircons with mean size of $200 \mu \mathrm{m}$ were extracted from the gray orthogneiss. Th/U determined on the grain sectors with oscillatory zoning ranges from 0.30 to 0.62 . Data reduction indicates two zircons with high $\mathrm{U}(\# 1, \# 9)$ and one with high ${ }^{204} \mathrm{~Pb}(\# 8)$. Discarding these grains, the data align on a discordia with an upper intercept at $2514 \pm 14 \mathrm{Ma}$ (MSWD, 1.8; Fig. 6A). However, if two discordant analyses (\#2 and \#7) are removed, the eleven spots define a mean ${ }^{207} \mathrm{~Pb} /{ }^{206} \mathrm{~Pb}$ age of $2496 \pm 40 \mathrm{Ma}$ (MSWD, 1.23), which is indistinguishable within the error limits from the upper intercept age. $\mathrm{Nd}$ model age yields $2.81 \mathrm{Ga}$ whereas $\varepsilon_{\mathrm{Nd}}$ returns a positive value assuming the crystallization age of the sample at $2.5 \mathrm{Ga}$.

Samples COR 1 and COR 2 come from gray, migmatized gneiss (metatextite; Fig. 3B) separated from each other by approximately $5 \mathrm{~km}$ (Fig. 4). The sample consists of granodioritic gneiss with biotite and green hornblende. Apatite and epidote are accessory minerals, with apatite normally being found as inclusions within the biotite. We investigate, respectively, nineteen and fifteen zircons extracted from the mesocratic sectors of the migmatite. Zircons of both samples usually show concentric zoning, although locally some overgrowths characterized on CL images by homogeneous, dark $\mathrm{U}$ - rich sectors can be observed in the grain margin (Fig. 7A). Th/U located on the concentric sectors typically range from 0.20 to 1.26 , although in two overgrowths (spots \#5 and \#12) the Th/U is less than 0.15. An upper intercept age of $2498 \pm 7 \mathrm{Ma}$ (MSWD, 1.18) is calculated for the sample COR1 after removing one analysis that plots above the concordia and two analyses that plot out to the discordia line (Fig. 6B). Thirteen analyses of the sample COR2, in turn, yield an upper intercept age of $2487 \pm 11 \mathrm{Ma}$, similar to that of the COR 1 sample. The spot is focused on two zircon overgrowths (Fig. 7A) and defines a lower intercept age of $563 \pm 27 \mathrm{Ma}$. These results suggest that these rocks crystallized in the Eosiderian, with the Neoproterozoic high-grade metamorphism accounting for the zircon overgrowths and partial resetting of the U-Pb system. The calculated $\varepsilon_{\mathrm{Nd}}$ values for the zircon age of these samples range from positive (2.28) to slightly negative $(-1.77)$ with a $\mathrm{T}_{\mathrm{DM}}$ of $2.54 \mathrm{Ga}$ and $2.84 \mathrm{Ga}$, respectively (Tab. 1).

Two samples (SM and AUR) provided Rhyacian ages. The first sample comes from an orthogneiss (SM) situated to the Northeast of Coremas Dam (Fig. 4) and consists of a granitic gneiss including augen-type coarse K-feldspar aligned parallel to the foliation defined by biotite. Ten analyses focused on the concentric zircon zoning show Th/U values between 0.33 and 0.93 . After discarding one analysis that plots above the concordia, nine zircons align on a discordia to provide an upper intercept age of $2197 \pm 35 \mathrm{Ma}$ (MSWD, 0.73; Fig. 6D). The second sample is situated to the South of the Lavras da Mangabeira duplex. Sixteen zircons collected from a fine porphyritic gray orthogneiss locally invaded by felsic leucossomes provided $\mathrm{Th} / \mathrm{U}$ between 0.14 and 0.76 . The zircons define a discordia with an upper intercept age of $2198 \pm 30 \mathrm{Ma}$ (MSWD, 2.8). Seven grains (\#1, \#2,\#7, \#8, \#11, $\# 12$ and \#15), however, plot next to the concordia and yield a mean ${ }^{207} \mathrm{~Pb} /{ }^{206} \mathrm{~Pb}$ age of $2178 \pm 7 \mathrm{Ma}$ (MSWD, 1.8; Fig. $6 \mathrm{E}$ ), 
Braz. J. Geol. (2021), 51(2): e20200132

Table 1. Sm-Nd isotope data for gneisses and migmatites of the Archean and Siderian age.

\begin{tabular}{|c|c|c|c|c|c|c|c|c|c|c|c|c|c|}
\hline Sample & rock & $\begin{array}{l}\text { Coord } \\
\text { UTM }\end{array}$ & $\begin{array}{l}\text { linates } \\
{ }^{*} \mathbf{2 4 M}\end{array}$ & $\begin{array}{c}\text { Sm } \\
(\mathbf{p p m})\end{array}$ & $\begin{array}{c}\text { Nd } \\
(\mathbf{p p m})\end{array}$ & $\begin{array}{c}147 \mathrm{Sm} / \\
144 \mathrm{Nd}\end{array}$ & Error & $\begin{array}{c}\text { 143Nd/ } \\
144 N d\end{array}$ & Error & $\begin{array}{c}\mathbf{N d} \\
(\mathbf{t}=\mathbf{0})\end{array}$ & $\begin{array}{l}\text { Age }^{1} \\
(\mathbf{G a})\end{array}$ & $\begin{array}{l}\text { Nd } \\
(\mathbf{t})\end{array}$ & $\begin{array}{c}\text { TDM } \\
\text { model } \\
\text { age }(G a)\end{array}$ \\
\hline Cor-1 & migmatite & 608018 & 9226122 & 11.205 & 62.818 & 0.1079 & 0.0006 & 0.511089 & 0.000006 & -30.21 & 2.49 & -1.77 & 2.84 \\
\hline Cor-2 & migmatite & 603517 & 9226828 & 3.065 & 20.659 & 0.0897 & 0.0005 & 0.510990 & 0.000007 & -32.14 & 2.50 & 2.28 & 2.54 \\
\hline LM-10(a) & orthogneiss & 500123 & 9259584 & 8.077 & 51.175 & 0.0954 & 0.0006 & 0.510803 & 0.000006 & -35.79 & 2.79 & 0.59 & 2.92 \\
\hline LM-30 & $\begin{array}{c}\text { banded } \\
\text { gneiss }\end{array}$ & 502627 & 9240544 & 14.651 & 76.861 & 0.1153 & 0.0007 & 0.511005 & 0.000007 & -31.86 & 2.77 & 2.77 & 3.21 \\
\hline LM-33 & $\begin{array}{c}\text { banded } \\
\text { gneiss }\end{array}$ & 489939 & 9251470 & 13.056 & 58.648 & 0.1346 & 0.0008 & 0.511604 & 0.000007 & -20.17 & 2.51 & 2.51 & 2.81 \\
\hline CAJ-03 & migmatite & 546373 & 9234170 & 27.070 & 127.976 & 0.1279 & 0.0008 & 0.511619 & 0.000006 & -19.89 & 2.45 & 2.40 & 2.55 \\
\hline JMR-1-1(b) & $\begin{array}{l}\text { biotite } \\
\text { gneiss }\end{array}$ & 508517 & 9253645 & 11.666 & 105.749 & 0.0667 & 0.0004 & 0.510503 & 0.000011 & -41.65 & 2.35 & 2.35 & 2.65 \\
\hline JMR-1-2(b) & $\begin{array}{l}\text { biotite } \\
\text { gneiss }\end{array}$ & 508517 & 9253645 & 5.816 & 36.156 & 0.0973 & 0.0006 & 0.510991 & 0.000015 & -32.13 & 2.35 & 2.35 & 2.71 \\
\hline A-41(c) & orthogneiss & n.a & & 3.898 & 17.469 & 0.1349 & n.a & 0.511425 & n.a & -23.13 & 2.45 & -3.53 & 3.10 \\
\hline SL9(a) & $\begin{array}{c}\text { banded } \\
\text { gneiss }\end{array}$ & 742680 & 9229990 & 13.469 & 106.526 & 0.0764 & 0.0005 & 0.510715 & 0.000012 & -37.61 & 2.40 & -0.39 & 2.60 \\
\hline
\end{tabular}

${ }^{1} \mathrm{Nd}(\mathrm{t}$ ) values calculated from U-Pb zircon ages quoted in this study and, (A) Hollanda et al. (2011, 2015), (B) Bautista (2012), (C) Ferreira et al. (2019). See text for abbreviation of the studied samples; ${ }^{*}$ Datum: Córrego Alegre.
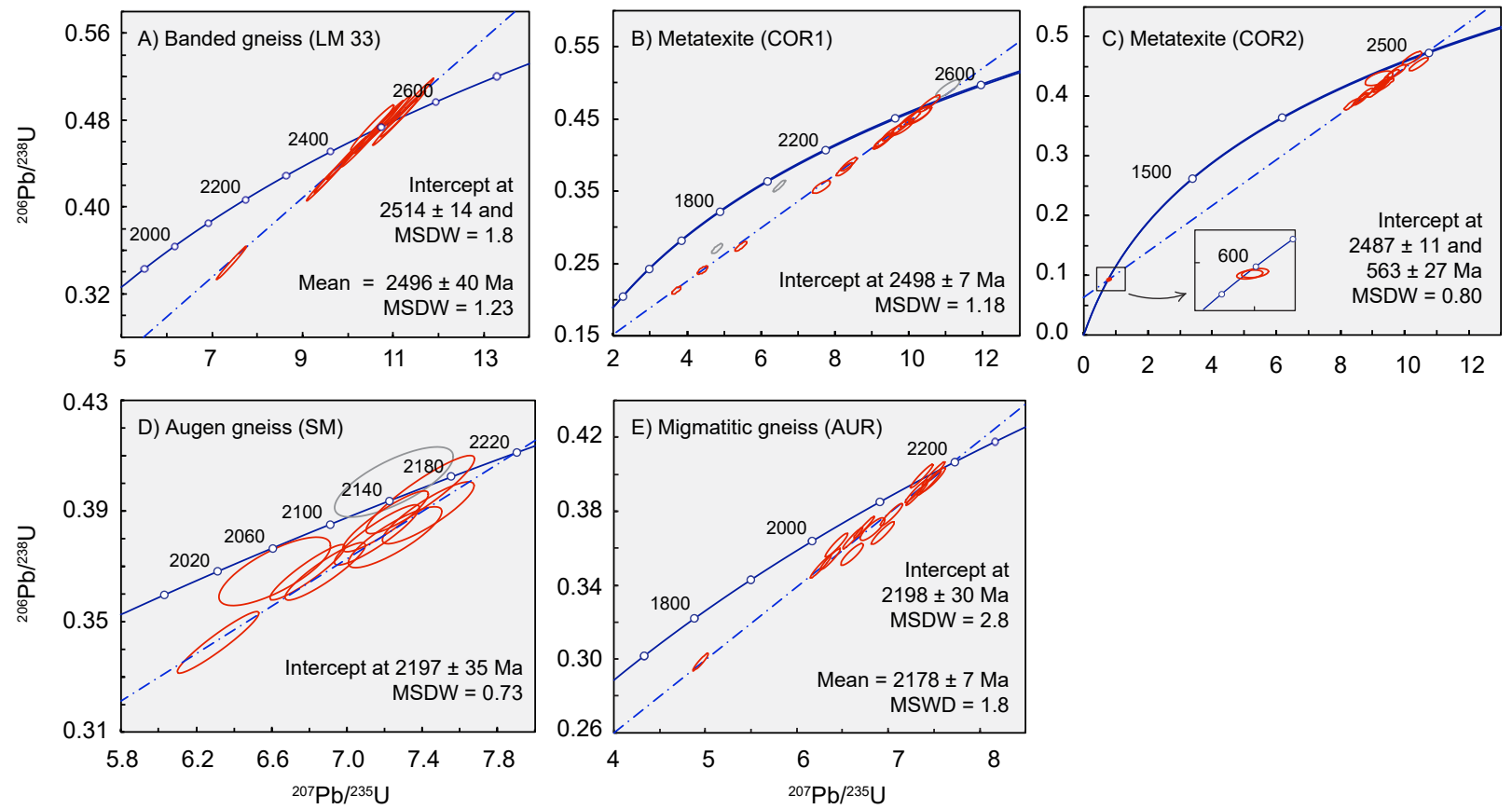

Figure 6. (A, B, C) Siderian and (D, E) Rhyacian zircon U-Pb ages of high-grade rocks in the Patos shear zone (see text for details).

which is indistinguishable from the confidence error of the intercept age. We consider mean age as the best estimate for the crystallization age of the sample AUR.

The migmatization age was investigated in samples CAJ3 and CIPA, coming from migmatites with high degree of partial melting (diatexite), including local pods of calc-silicate and/or mafic rocks (Fig. 3D) that most likely represent the unmelted residue of the host-rock. Sample CAJ3 comes from a mesosome of granitic composition with the foliation outlined by a large biotite. The amphibole is an accessory mineral, often partially replaced by epidote and/or chlorite. Among sixteen zircons with oscillatory zoning, four show Archean to Paleoproterozoic ages (Fig. 7B) and are considered inherited grains. One zircon with a high common $\mathrm{Pb}$ provides a younger age and is discarded. Ten zircons with Th/U typically above 0.4 , in contrast, are plotted close to the concordia and define an average ${ }^{206} \mathrm{~Pb} /{ }^{238} \mathrm{U}$ age of $565 \pm 9 \mathrm{Ma}$ (MSWD, 1.48; Fig. 8). This sample provides a Sm-Nd $\mathrm{T}_{\mathrm{DM}}$ age of $2.55 \mathrm{Ga}$ and a positive $\varepsilon_{\mathrm{Nd}}(2.4)$ if the protolith formed in the Siderian $(\mathrm{t}=2.45 \mathrm{Ga})$ is considered. 
The CIPA sample comes from a dark layer of dioritic composition. The mafic silicates are dominated by large, clean biotite grains whereas the amphibole is altered to chlorite and epidote. Zircons usually form elongated crystals with aspect ratios ranging from 2:1 to 5:1. On the CL image (Fig. 7C),

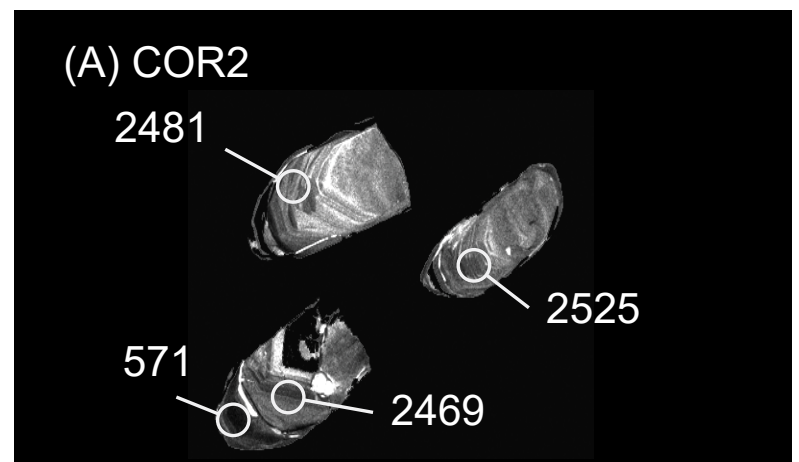

(B) CAJ3

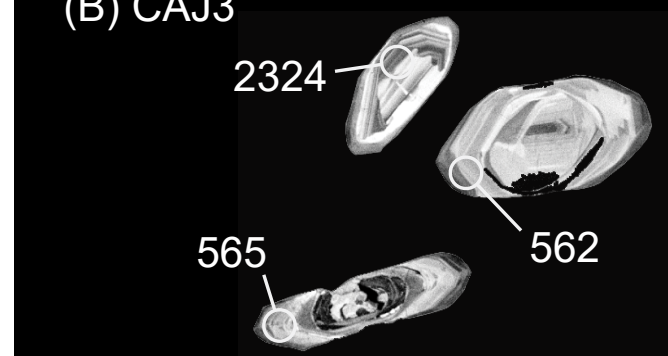

(C) CIPA

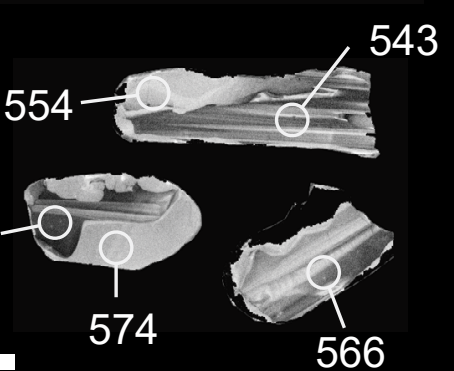

$200 \mu \mathrm{m}$

Figure 7. Cathodoluminescence image of zircons with corresponding ages $(\mathrm{Ma})$ of migmatites from the $(\mathrm{A})$ central and (B, C) Western branches of the Patos shear zone. they often show crystal-parallel zoning defined by U-poor and U-rich areas occasionally truncated by more homogeneous patchy sectors. Th/U are usually higher than 0.2 , although two spots focused on homogeneous sectors provided $\mathrm{Th} / \mathrm{U}$ $=0.09$. Ages from twenty analyses of both zoned and more homogeneous sectors are indistinguishable within the error limits. All analyses plot on the concordia to yield an average ${ }^{206} \mathrm{~Pb} /{ }^{238} \mathrm{U}$ age of $566 \pm 6 \mathrm{Ma}$ (MSWD, 0.74; Fig. 8). Moreover, a concordia age for the same zircon population yields $566 \pm$ $3 \mathrm{Ma}(1 \sigma ; \mathrm{MSWD}, 1.02)$. The results for samples CAJ3 and CIPA therefore indicate that the peak of high-grade regional metamorphism occurred in the late Ediacaran at approximately 565 Ma.

\section{$\mathrm{Ar} / \mathrm{Ar}$}

The amphibole and biotite was extracted from sample COR2, evidencing Neoproterozoic zircon overgrowths (Figs. 6C and 7A), and biotite from the two diatexite samples (CAJ3 and CIPA), providing a late Ediacaran $\mathrm{U}-\mathrm{Pb}$ zircon ages. As for CAJ3 and CIPA samples, the amphiboles are partially replaced with epidote and chlorite and were not analyzed by the ${ }^{40} \mathrm{Ar} /{ }^{39} \mathrm{Ar}$ method. See Figure 9 for results.

Incremental step-heating analyses of two amphibole separates from the sample COR2 yield plateau ages of $565 \pm 2$ and $566 \pm 1.7 \mathrm{Ma}$ from mid- to high-temperature heating intervals. The total gas ages of these samples are slightly lower than the respective plateau-ages, which can be attributed to age uncertainties from the initial steps on both spectra, as well as Ar-excess recorded in their final steps. The biotite, in contrast, shows disturbed step-heating spectra. One separate spectrum provides a plateau age of $549 \pm 1.6 \mathrm{Ma}$, whereas the other does not define a plateau. The total gas ages for these aliquots yielded, respectively, ages of 542 and 544 Ma.

The biotite in the CAJ3 and CIPA samples, on the other hand, yields well-defined plateau-ages of $544 \pm 1.4$ and $542 \pm$ 1.6 Ma and $533 \pm 1.4 \mathrm{Ma}$ (Fig. 9), respectively. The total gas ages are indistinguishable from the plateau-age at the $2 \sigma$ level. These ages are attributed to cooling after the peak high-grade metamorphism of the shear zone.
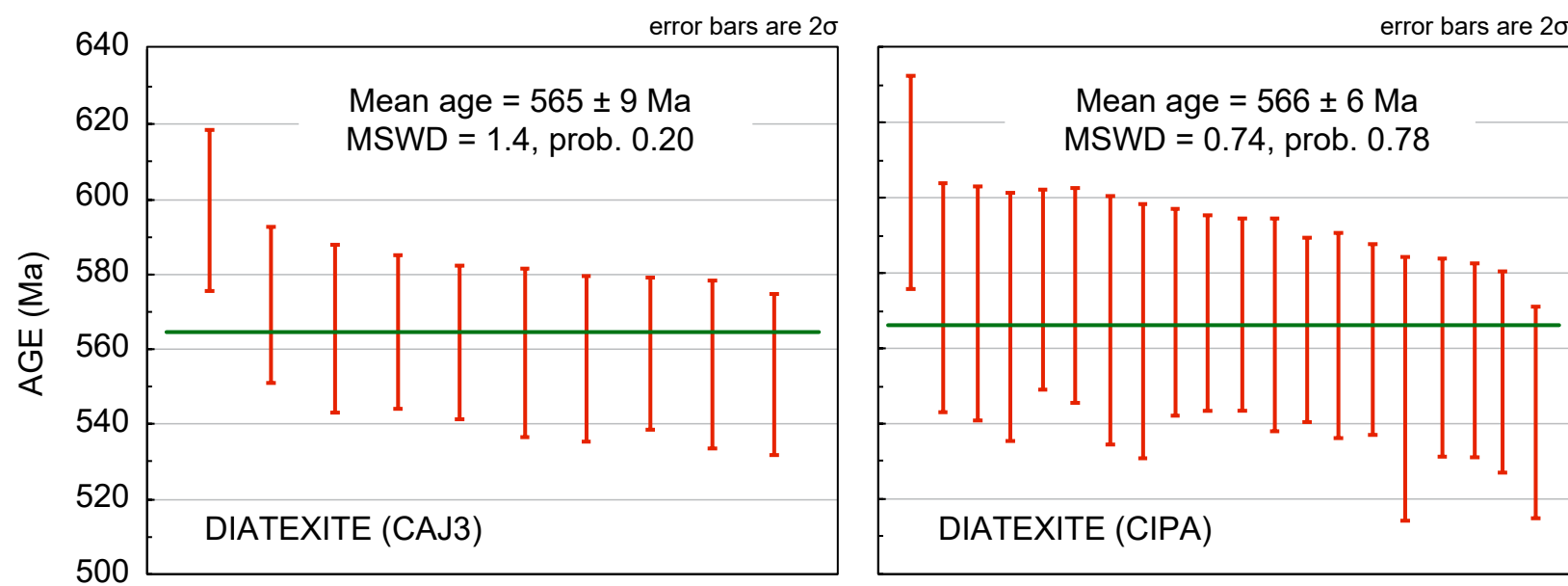

Figure 8. Average ${ }^{206} \mathrm{~Pb} /{ }^{238} \mathrm{U}$ zircon ages of migmatites from the Western branch of the Patos shear zone. 

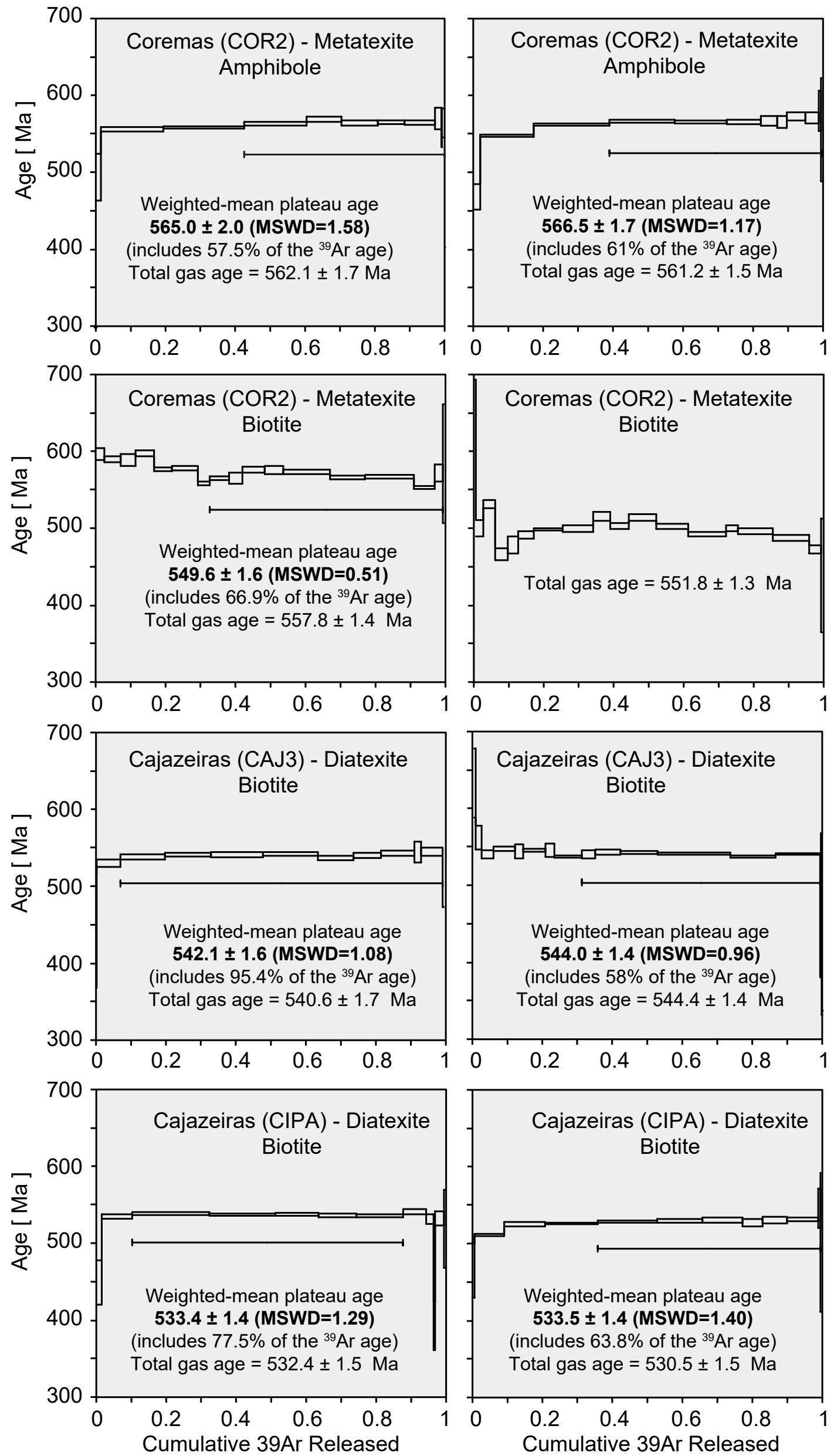

Figure 9. Argon-release age spectra for amphibole (top) and biotite from migmatites of the Western branch of the Patos shear zone. Bars are representative of $2 \sigma$ errors (see text for details). 


\section{DISCUSSION}

\section{Connecting the Seridó belt and the Granjeiro complex}

According to Silva et al. (1997), the Granjeiro Complex consists of bimodal tonalitic to granodioritic (locally trondjhemitic) rocks, including mafic lenses of tholeiitic amphibolite. This unit is defined near the town of Granjeiro (see Fig. 4) and occurs as slices in the Lavras da Mangabeira duplex. A Neoarchean age $(2.54 \mathrm{Ga})$ is provided by a U-Pb SHRIMP analysis of zircons from a tonalitic gneiss interleaved with mafic layers. More recently, Hollanda et al. (2015) provided an age of $2.79 \mathrm{Ga}$ for a granodioritic gneiss that constitutes the basement of a metasedimentary unit consisting of pelite, quartzite and conglomerate, all units deformed in the duplex structure. Detrital zircons from metapelites indicate that they were deposited in the Neoproterozoic (Hollanda et al. 2015). The remarkable similarities recorded in the detrital zircon spectra of the Lavras da Mangabeira and Seridó metasedimentary rocks, including some slices of metapelite and quartzite exposed along the central segment of the Patos shear zone, constitute a firm evidence connecting the Lavras da Mangabeira units to the Seridó belt.

The results extend the occurrence of the Granjeiro Complex by at least a hundred kilometers in length between the Coremas Dam and the Granjeiro town. Two belts parallel to the shear zone can be distinguished, one aged between 3.0 and ca. $2.5 \mathrm{Ga}$ and the other between ca. 2.5 and $2.36 \mathrm{Ga}$ (Fig. 4). The Archean belt mostly consists of banded rocks and metagranitoids, whereas the Siderian belt comprises migmatitic granodioritic to granitic gneisses in addition to local banded gneiss. Amphibolite and metaultramafic rocks occur in both sequences (Bautista 2012, Freimann 2014). Banded gneiss of Siderian age has also been recorded in the connection between the Patos shear zone and the Seridó belt (Hollanda et al.2011), which highlights the lithological similarity between these Archean and Siderian sequences. The $\varepsilon_{\mathrm{Nd}}$ calculated for the age of rock formation yields mostly positive values, showing a juvenile component, although the contribution of ancient crustal material cannot be eliminated as indicated by slightly negative $\varepsilon_{\mathrm{Nd}}$ values recorded in some samples (cf. Tab. 1).

The similar rock types and $\mathrm{Sm}-\mathrm{Nd}$ isotope compositions therefore allow us to extend the definition of the "Granjeiro Complex" as a suite of metagranitoids including metamafic and metaultramafic rocks that locally contain metacherts, marbles and BIFs. The strong deformation of the Patos shear zone must account for the banded aspect of these rocks. U-Pb zircon ages range mainly between 3.0 and $2.35 \mathrm{Ga}$, and $\varepsilon_{\mathrm{Nd}}$ indicate a net contribution of juvenile material. In the Central and Western segments of the shear zone, these units form the basement of the Neoproterozoic metasedimentary sequences and both occur sandwiched between Rhyacian orthogneisses dated 2.1 to $2.2 \mathrm{Ga}$. (samples SM and AUR). The Rhyacian orthogneisses, in turn, must be linked to the Caicó Complex, which is exposed over large areas to the North of the Patos shear zone. The Siderian and Rhyacian sequences show varying degrees of partial melting that form metatexite, diatexite and even nebulite migmatites. Kinematic criteria such as asymmetric boudinaged leucosomes, fold vergence and S-C foliation fabrics, all implying that partial melting was synchronous with the dextral shear movement (Viegas et al. 2013, Cavalcante et at. 2016).

\section{HT-metamorphism and cooling of the Patos shear zone}

Evidence that migmatization in the Central Patos shear zone occurred in the late Ediacaran was first introduced by Viegas et al. (2014). They showed that the recrystallized margin of zircon grains in diatexites yielded concordant $\mathrm{U}-\mathrm{Pb}$ ages of ca. $565 \mathrm{Ma}$, whereas their cores provided Rhyacian ages. A consequence of these results was that partial melting of the host regional rocks occurred as the shear zone was active under high-temperatures. Our zircon $\mathrm{U}-\mathrm{Pb}$ data for migmatites from the West Patos shear zone confirm these findings. The average ages of concordant zircons are consistent with a late Ediacaran partial melting which, in turn, indicates that the strike-slip duplex would be a late structure formed during this high-temperature event. Evidence from inherited zircons (sample CAJ3) and the upper intercept ages of ca. $2.48 \mathrm{Ga}$ of some diatexites (COR1 and COR2) indicate that the Siderian rocks were deeply involved in partial melting. Moreover, concordant ages from the cores and the margin of the zircons from the sample CIPA suggest that, at least locally, the zircons were fully recrystallized at a high-temperature.

The cooling of the migmatites was estimated using the hornblende and biotite's closure temperature through the ${ }^{40} \mathrm{Ar} /{ }^{39} \mathrm{Ar}$ method. The mineral-specific closure temperature for Ar diffusion, however, depends on many variables such as grain size, composition, diffusion coefficients and cooling rate (Dodson 1973). Cooling rates, in turn, can vary between tectonic settings (Scibiorski et al.2015) and apparently through geological time, as the cooling rate tends to decrease with increasing orogenic age (Dunlap 2000, Willigers et al. 2002). The slower cooling rates recorded in Precambrian orogens have been attributed to a sampling bias, since older orogens tend to expose deeper and therefore "warmer" sections of the crust compared to the Phanerozoic orogens (Willigers et al. 2002). We seek to overcome such uncertainties by comparing rocks from the same tectonic setting (shear zone) that were subjected to the same metamorphic conditions above the closure temperature of hornblende and biotite, typically at $\sim 550$ and $\sim 310^{\circ} \mathrm{C}$, respectively (Harrison 1982, Harrison et al. 1985, Dahl 1996).

Rocks such as metapelite, metagraywacke and granite may start to melt in the presence of excess water when the metamorphic temperature exceeds $650^{\circ} \mathrm{C}$, and the melt they produce is granitic in its composition. In fluid-absent melting, however, metagraywackes and meta-andesites start to melt between 750 and $800^{\circ} \mathrm{C}$ (Sawyer et al. 2011). As migmatites and rocks of pelitic composition are frequently observed along the shear zone, sometimes side-by-side, we estimate that migmatites formed by partial melting would have occurred at relatively high water-fluid pressures at $\sim 700^{\circ} \mathrm{C}$. Assuming a linear decrease in temperature after the metamorphic peak in the shear zone at ca. $565 \mathrm{Ma}$, we calculate cooling rates of $12^{\circ} \mathrm{C} / \mathrm{Ma}$ (CIPA), $16^{\circ} \mathrm{C} / \mathrm{Ma}\left(\mathrm{CAJ} 3\right.$ ) and $17^{\circ} \mathrm{C} / \mathrm{Ma}$, the latter using the 
hornblende-biotite pair of the sample COR2. These rates are higher than that of approximately $4^{\circ} \mathrm{C} / \mathrm{Ma}$ estimated at the connection between the Seridó belt and the Patos shear zone (Corsini et al. 1998).

These heterogeneous cooling rates over relatively short distances $(<150 \mathrm{~km})$ were attributed by Monié et al. (1997) to variation in the width of high-temperature anastomosing mylonite zones enclosing inner, less-deformed, migmatite domains. In addition, we consider that the deformation involved a component of shortening across the zone leading to differential exhumation, faster in the Western segment of the shear zone. A transpressive setting for the Patos-Seridó system (Corsini et al. 1991, Archanjo et al. 2002) is consistent with upward extrusion of Siderian fragments recorded in the shear zone and in the basement of the Serido metapelite. Older ${ }^{39} \mathrm{Ar} /{ }^{40} \mathrm{Ar}$ mica ages in the range of $550-560 \mathrm{Ma}$, in turn, are found further West in the Senador Pompeu and Tauá shear zones (Monié et al. 1997, Ávila et al. 2020), indicating faster cooling in the Ceará Central domain when compared to the Patos-Seridó belt.

\section{Lateral escape tectonics}

The distribution of Archean and Siderian rocks along the Seridó, Lavras da Mangabeira and Ipueirinha belts can be followed along a NE- to E-trending corridor between the Potiguar and Paranaíba basins (Fig. 2). Siderian rocks have been recorded to the North and South of the Seridó belt (Ferreira et al. 2019, Hollanda et al. 2011), between the Coremas Dam and Granjeiro town (this study; Freimann 2014) and to the Southwest next to the Pernambuco shear zone (Pitarello et al. 2019). Archean rocks occur in the basement of the Seridó belt (Dantas et al. 2013, Ferreira et al. 2020), on well-logs from samples to the West of the Serido metapelites (Cavalcante et al. 2018), in the Lavras da Mangabeira duplex (this study, Hollanda et al.2015, Silva et al. 1997), and in the Ipueirinha belt (Pitarello et al.2019). The Siderian units, in particular, consist of an allochthonous sequence with no record in the basement of the Northern Borborema, except rimming the Seridó belt and next to the Transbrasiliano Lineament. Occurrences of Siderian rocks close to the Seridó and Lavras da Mangabeira basins suggest that zones of crustal discontinuity would have controlled their distribution, possibly by crustal shortening and reactivation of the deep fault zones. In addition, these basement sequences may have moved long distances laterally through strike-slip shear movements.

Extrusion is a concept in which a smaller continent or continental sliver escapes laterally between two larger continents in a convergent setting. The lateral movement is accommodated mainly by strike-slip faults usually connected to the collisional front, such as the Ailao-Red River shear zone, in Indochina (Leloup et al. 1995, Cao et al.2012, Liu et al.2020), and the North Anatolian continental transform in the Middle East (Norris and Toy 2014). The lateral displacement of these fault zones has been estimated at ca. $80 \mathrm{~km}$ in the active North Anatolian transform (Sengor et al. 2005) and over $500 \mathrm{~km}$ in the Indochina block (Liu et al. 2020 and references therein). According to Ganade de Araújo et al. (2013), the extrusion of the Borborema Province would occur by the combined movement of the dextral Transbrasiliano Lineament and northward indentation of the São Francisco-Congo craton. The deformation in the shear zones would record two discrete collisional events, being the first one at c. $620-610 \mathrm{Ma}$, which resulted in the closure of the Goiás-Pharusian Ocean (collision I), and a second event between. $590 \mathrm{Ma}$ and 560 Ma that resulted in the extrusion of the province (collision II). The extrusion would require anticlockwise rotation of the Northern Borborema domain to accommodate the dextral displacement on the Transbrasiliano Lineament.

Our results, in contrast, are consistent with an E-W collision and convergence between the São Francisco-Congo and the Amazonian cratons between $580 \mathrm{Ma}$ and 550 (Fig. 10). The dextral Patos (and Pernambuco) strike-slip shear zone would accommodate the westward displacement of the São Francisco-Congo craton allowing the lateral escape to the East and Northeast of the Borborema terranes. Bulk compression/transpression in the frontal and lateral margins of the São Francisco paleocontinent would partition the deformation to detach and thrust the low-grade marginal sequences upon the craton (Fig. 1B). It can be speculated, in addition, that at least part of the Siderian fragments could have been detached from the craton margins, transported along shear corridors and emplaced within the Borborema Province. This is consistent with the Sm-Nd $\mathrm{T}_{\mathrm{DM}}$ model ages recorded in the Siderian rocks of the Borborema and Tocantins provinces (Santos et al. 2009, Fuck et al. 2014) and São Francisco craton (Barbosa et al.2019). Furthermore,

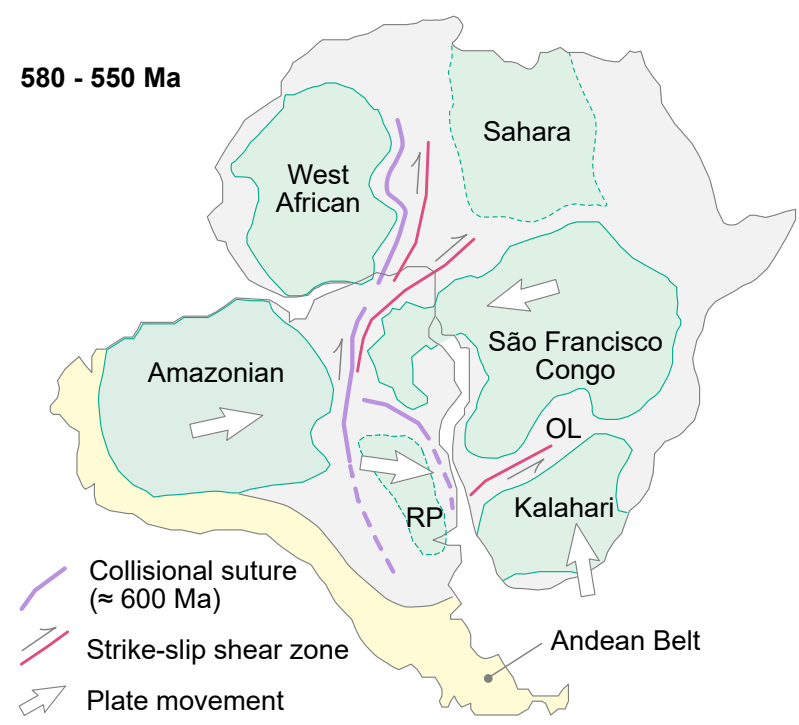

Figure 10. Schematic reconstruction of the tectonic setting of the West Gondwana in the $580-550 \mathrm{Ma}$ interval. Collisional sutures (inferred when dashed) assembled the West African, Amazonian and São Francisco-Congo cratons at ca. $600 \mathrm{Ma}$ (collisional stage I after Ganade de Araújo et al. 2013), and the ongoing convergence between São Francisco-Congo and Amazonian cratons extruding the Borborema through strike-slip shear zones. Further South (today geographic coordinates), late collisions of the Rio de la Plata-Paranapanema (RP) and Kalahari cratons (Goscombe et al. 2017) close the assembly of the West Gondwana. The left-lateral displacement of Okahandja Lineament (OL, Downing and Coward 1981 ) in the Damara belt is consistent with the westward movement of the São-Francisco-Congo craton (see text). 
plate configurations between 580 - $550 \mathrm{Ma}$ indicate convergence and collision between the cratonic blocks of SãoFrancisco-Congo, Rio de la Plata-Paranapanema and Kalahari cratons to form, respectively, the Kaoko and Damara orogenic belts (Passchier et al. 2016, Goscombe et al. 2017). The left-lateral differential movement between the Central and Southern Zone of the Damara belt (Downing and Coward 1981) agrees with the bulk westward displacement of the São Francisco-Congo craton.

Granitic magmatism and syn-kinematic partial melting of the Patos shear zone and the Seridó belt indicates that during the 580 - $550 \mathrm{Ma}$ interval, the Borborema orogenic core was partially molten. Unstable dripping of the lithosphere that resulted from a warmer Precambrian mantle (Fischer and Gerya 2016) coupled with post-collisional extension would promote partial melting in high-strain zones, reduction of rock strength and development of lateral escape tectonics. In Asia, the high-grade metamorphism and extrusion of the Indochina occurred approximately $20 \mathrm{Ma}$ after the India collision and was followed by delamination of the lithospheric mantle and emplacement of K-richer felsic melts (Liu et al. 2020). Similar time scales are recorded in the Borborema Province, with the closure of the Goiás-Pharusion Ocean ending at ca. $600 \mathrm{Ma}$ (Ganade de Araújo et al. 2014) and high-temperature strike-slip movements dated at ca. $585 \mathrm{Ma}$ in the Senador Pompeu and Tauá shear zones (Ávila et al. 2019), and at ca. $565 \mathrm{Ma}$ in the Patos shear zone. Based on the consistent dextral kinematics over a thousand kilometers, the occurrence of allochthonous (Siderian) sequences and geophysical evidence (Oliveira and Medeiros 2018), it is estimated that the SeridóGranjeiro corridor constitutes a major crustal boundary presumably connected to the collisional front between the São Francisco and Amazonian cratons.

\section{CONCLUSION}

Evidence from zircon $\mathrm{U}-\mathrm{Pb}$ and $\mathrm{Sm}-\mathrm{Nd}$ isotopic compositions defines two belts parallel to the West Patos shear zone, with Meso- to Neoarchean and Siderian ages. These belts characterize the Granjeiro Complex, which shows a net juvenile component between approximately 2.80 and $2.35 \mathrm{Ga}$. The occurrences of Archean and Siderian rocks scattered along the Patos shear zone combined with prominent magnetic anomaly trends confirm the connection between the GranjeiroSeridó and Ipueirinha basement sequences. Furthermore, the pelitic basins developed along major crustal discontinuities and were subsequently reactivated at a high temperature and deformed by dextral shear.

The migmatization age indicates that the metamorphic peak occurred in the late Ediacaran at ca. $565 \mathrm{Ma}$, with leucosomes deformed by the shear zone movement. The ${ }^{40} \mathrm{Ar} /{ }^{39} \mathrm{Ar}$ step-heating plateau-ages in hornblende and biotite from migmatites show moderate to fast cooling rates and contrast with the slower cooling recorded in the central branch of the shear zone. These heterogeneous cooling rates agree with differential uplift, faster in the Western shear zone branch. The systematic dextral kinematic and allochthonous Siderian basement rocks that can be traced for hundreds of kilometers dispersed along the shear zone are consistent with a major tectonic boundary that merged towards the collisional front between the São Francisco and Amazonian cratons. Accordingly, the Patos (and Pernambuco) shear zone would accommodate the lateral escape tectonics that resulted from the westward convergence of the São Francisco-Congo craton.

\section{ACKNOWLEDGMENTS}

The authors acknowledge the Brazilian agencies FAPESP, CNPq and CAPES, for having provided support for several years, and more recently through grants 304979/2016-3 (CJA) and 305824/2014-7 (MHBMH). Carlos Archanjo and Gustavo Viegas thank FAPESP for making this research possible (grant 2014/01114-2). We thank the journal reviewers, Sérgio Neves and Fabrício Caxito, who provided useful remarks that helped to clarify and improve the manuscript, and Haakon Fossen for the comments and editorial handling.

\section{ARTICLE INFORMATION}

Manuscript ID: 20200132. Received on: 12/21/2019. Approved on: 03/04/2021.

C.J.A.: conceptualization, methodology, formal analysis, fund acquisition, writing. M.H.H.: methodology, formal analysis, fund acquisition, review. L.G.V.: methodology, data curation, review.

Competing interest: The authors declare no competing interests.

\section{REFERENCES}

Archanjo C.J., Trindade R.I.F., Bouchez J.L., Ernesto M. 2002. Granite fabrics and regional-scale strain partitioning in the Seridó belt (Borborema Province, NE Brazil). Tectonics, 21(1):3-1-3-14. https://doi. org/10.1029/2000TC001269

Ávila C.F., Archanjo C.J., Fossen H., Hollanda M.H.B.M. 2019. Zippered shear zone model in the Borborema Province, Brazil, as constrained by U-Pb dating. Tectonics, 38(11):3959-3974. https://doi.org/10.1029/2019TC005547

Ávila C.F., Archanjo C.J., Hollanda M.H.B.M., Macêdo Filho A.A., LemosSantos D.V. 2020. Shear zone cooling and fabrics of synkinematic plutons evidence timing and rates of orogenic exhumation in the Northwest Borborema Province (NE Brazil). Precambrian Research, 350:105940. https://doi.org/10.1016/j.precamres.2020.105940
Barbosa N., Teixeira W., Ávila C.A., Montecinos P.M., Bongiolo E.M., Vasconcelos E.F. 2019. U-Pb geochronology and coupled Hf-Nd-Sr isotopic-chemical constraints of the Cassiterita orthogneiss (2.47-2.41 $\mathrm{Ga}$ ) in the Mineiro belt, São Francisco craton: Geodynamic fingerprints beyond the Archean-Paleoproterozoic transition. Precambrian Research, 326:399-416.

Basto C.F., Caxito F.A., Vale J.A.R, Silveira D.A., Rodrigues J.B., Alkmin A.R., Valeriano C.M., Santos E.J. 2019. An Ediacaran back-arc basin preserved in the Transversal Zone of the Borborema Province: Evidence from geochemistry, geochronology and isotope systematics of the Ipueirinha Group, NE Brazil. Precambrian Research, 320:213-231. https:// doi.org/10.1016/j.precamres.2018.11.002 
Bautista J.M.R. 2012. Estudo de proveniência sedimentar de sequências neoproterozoicas ao longo do Lineamento Patos (Província Borborema, NE Brasil). Dissertation, Instituto de Geociências, Universidade de São Paulo, São Paulo, 62 p.

Caby R. 1989. Precambrian terranes on Benin-Nigeria and Northeast Brazil and the Late Proterozoic South Atlantic fit. Geological Society of America, Special Paper 230, p. 145-15. https://doi.org/10.1130/SPE230-p145

Caby R., Arthaud M.H., Archanjo C.J. 1995. Lithostratigraphy and petrostructural characterization of supracrustal units in the Brasiliano belt of Northeast Brazil: geodynamic implications. Journal of South American Earth Sciences, 8(3-4):235-246. https://doi. org/10.1016/0895-9811(95)00011-4

Cao S., Liu J., Leiss B., Vollbrecht A., Genser J., Neubauer F., Zhao C. 2012. Initiation of left-lateral deformation along the Ailao Shan-Red River shear zone: new microstructural, textural and geochronological constraints from the Diancang Shan metamorphic massif, SW Yunnan, China. International Geology Review, 54(3):348-367. https://doi.org/10.1080/00206814.2010 .543789

Castro D.L., Fuck R.A., Phillips J.D., Vidotti R.M., Bezerra F.H.R., Dantas E.L. 2014. Crustal structure beneath the Paleozoic Parnaíba basin revealed by airbone gravity and magnetic data, Brazil. Tectonophysics, 614:128-145. https://doi.org/10.1016/j.tecto.2013.12.009

Cavalcante G.C.G., Viegas L.G., Archanjo C.J., Silva M.E. 2016. The influence of partial melting and melt migration on the rheology of the continental crust. Journal of Geodynamics, 101:186-199. https://doi.org/10.1016/j. jog.2016.06.002

Cavalcante R., Medeiros V.C., Costa A.P., Sá J.M., Santos R.V., Rodrigues J.B., Dantas A.R., Nascimento M.A.L., Cunha A.L.C. 2018. Neoarchean, Rhyacian and Neoproterozoic units of the Saquinho region, Eastern Rio Piranhas-Seridó domain, Borborema Province (Northeastern Brazil): implications for the stratigraphic model. Journal of the Geological Survey of Brazil, 1(1):11-29. https://doi.org/10.29396/jgsb.2018.v1.n1.2

Caxito F.A., Santos L.C.M.L., Ganade de Araújo C.E., Bendaoud A., Fettous E-H., Bouyo M.H. 2020. Towards an integrated model of geological evolution for NE Brazil-NW Africa: The Borborema Province and its connections to the Trans-Saharan Benino-Nigerian and Tuareg shields and Central African orogens. Brazilian Journal of Geology, 50(2):e20190122. https://doi.org/10.1590/2317-4889202020190122

Caxito F.A., Uhlein A., Stevenson R., Uhlein G. 2014. Neoproterozoic oceanic crust remnants in Northeast Brazil. Geology, 42(5):387-390. https://doi.org/10.1130/G35479.1

Cordani U.G., Ramos V.A., Fraga L.M., Cegarra M., Delgado I., de Souza K.G., Gomes E.F.M., Schobbenhaus C. 2016. Tectonic map of South America at 1:5.9 M. CGMW-CPRM-SEGEMAR

Corsini M., Figueiredo L.L., Caby R., Féraud G., Ruffet G., Vauchez A. 1998. Thermal history of the Pan-African/Brasiliano Borborema Province of Northeast Brasil deduced from ${ }^{40} \mathrm{Ar} /{ }^{39} \mathrm{Ar}$ analysis. Tectonophysics, $\mathbf{2 8 5}$ (12):103-117. https://doi.org/10.1016/S0040-1951(97)00192-3

Corsini M., Vauchez A., Archanjo C.J., Jardim de Sá E.F. 1991. Strain transfer at a continental scale from a transcurrent shear zone to a transpressional fold belt: the Patos-Seridó belt system, Northeastern Brazil. Geology, 19(6):586589. https://doi.org/10.1130/0091-7613(1991)019\%3C0586:STACSF\% 3E2.3.CO;2

Corsini M., Vauchez A., Caby R. 1996. Ductile duplexing at a bend of a continental scale strike-slip shear zone: example from $\mathrm{NE}$ Brazil. Journal of Structural Geology, 18(4):385-394. https://doi. org/10.1016/0191-8141(95)00102-J

Costa F.G., Klein E.L., Lafon J.M., Milhomem Neto J.M., Galarza M.A., Rodrigues J.B., Naleto J.L.C., Lima R.G.C. 2018. Geochemistry and $\mathrm{U}-\mathrm{Pb}$-Hf zircon data for plutonic rocks of the Troia Massif, Borborema Province, NE Brazil: Evidence for reworking of Archean and juvenile Paleoproterozoic crust during Rhyacian accretionary and collisional tectonics. Precambrian Research, 31 1:167-194. https://doi.org/10.1016/j. precamres.2018.04.008

Dahl P.S. 1996. The effects of composition on retentivity of argon and oxygen in hornblende and related amphiboles: A field-tested empirical model. Geochimica et Cosmochimica Acta, 60(19):3687-3700. https://doi. org/10.1016/0016-7037(96)00170-6
Daly M.C., Andrade V., Barousse C.A., Costa R., McDowell K., Piggott N., Poole A.J. 2014. Brasiliano crustal structure and the tectonic setting of the Parnaíba basin of NE Brazil: Results of a deep seismic reflection profile. Tectonics, 33(11):2102-2120. https://doi.org/10.1002/2014TC003632

Dantas E.L., Souza Z.S., Wernick E., Hackspacher P.C., Martin H., Xiaodong D., Li J.W. 2013. Crustal growth in the 3.4-2.7 Ga São José de Campestre Massif, Borborema Province, NE Brazil. Precambrian Research, 227:120156. https://doi.org/10.1016/j.precamres.2012.08.006

Davison I, Santos R.A. 1989. Tectonic evolution of the Sergipano fold belt NE Brazil, during the Brasiliano orogeny. Precambrian Research, 45(4):319342. https://doi.org/10.1016/0301-9268(89)90068-5

DePaolo D.J. 1981. Nd isotopic studies: some new perspectives on Earth structure and evolution. Transactions of the American Geophysical Union, 62(4):137-140. https://doi.org/10.1029/EO062i014p00137-01

Dodson M.H. 1973. Closure temperature in cooling geochronological and petrological systems. Contributions to Mineralogy and Petrology, 40:259-274. https://doi.org/10.1007/BF00373790

Domingos N., Medeiros W.E., Oliveira R.G. 2020. Geophysical evidence for doming during the Pan-African/Brasiliano orogeny in the Seridó belt, Borborema Province, Brazil. Precambrian Research, 350:105870. https:// doi.org/10.1016/j.precamres.2020.105870

Downing K., Coward M.P. 1981. The Okahandja Lineament and its significance for Damara tectonics in Namibia. Geologische Rundschau, 70:972-1000. https://doi.org/10.1007/BF01820175

Dunlap W.J. 2000. Nature's diffusion experiment: the coolingrate cooling-age correlation. Geology, 28(2):139-142. https://doi. org/10.1130/0091-7613(2000)28\%3C139:NDETCC\%3E2.0.CO;2

Ferreira A.C.D., Dantas E.L., Santos T.J.S., Fuck R.A., Tadeschi M. 2020. Highpressure metamorphic rocks in the Borborema Province, Northeast Brazil: Reworking of Archean oceanic crust during proterozoic orogenies. Geoscience Frontiers, 11 (6):2221-2242. https://doi.org/10.1016/j.gsf.2020.03.004

Ferreira A.C.D., Ferreira Filho C.F., Dantas E.L., Souza V.S. 2019 Paleoproterozoic mafic-ultramafic magmatism in the Northern Borborema Province, Northeast Brazil: Tectonic setting and potential for deposits. Journal of Geology, 127(5):483-504. https://doi.org/10.1086/704256

Fischer R., Gerya T. 2016. Regimes of subduction and lithospheric dynamics in the Precambrian: 3D thermomechanical modelling. Gondwana Research, 37:53-70. https://doi.org/10.1016/j.gr.2016.06.002

Freimann M.A. 2014. Geocronologia e petrotrama de quartzo milonito do duplex transcorrente de Lavras da Mangabeira, Ceará. Dissertation, Instituto de Geociências, Universidade de São Paulo, São Paulo, 82 p.

Fuck R.A., Dantas E.L., Pimentel M.M., Botelho N.F., Armstrong R., Laux J.H., Junges S.L., Soares J.E., Praxedes I.F. 2014. Paleoproterozoic crustformation and reworking events in the Tocantins Province, central Brazil: A contribution for Atlantica supercontinent reconstruction. Precambrian Research, 244:53-74. https://doi.org/10.1016/j.precamres.2013.12.003

Ganade de Araújo C.E., Cordani U., Weinberg R., Basei M.A.S., Armstrong R., Sato K. 2014. Tracing Neoproterozoic subduction in Borborema Province (NE Brazil): Clues from U-Pb geochronology and Sr-Nd-Hf-O isotopes on granitoids and migmatites. Lithos, 202-203:167-189. https:// doi.org/10.1016/j.lithos.2014.05.015

Ganade de Araújo C.E., Weinberg R., Cordani U.G. 2013. Extruding the Borborema Province (NE-Brazil): a two-stage Neoproterozoic collision process. Terra Nova, 26(2):157-168. https://doi.org/10.1111/ter.12084

Goscombe B., Foster D., Gray D., Wade B., Mersellos A., Titus J. 2017. Deformation correlations, stress field switches and evolution of an orogenic intersection: The Pan-African Kaoko-Damara orogenic junction, Namibia. Geoscience Frontiers, 8(6):1187-1232. https://doi.org/10.1016/j. gsf.2017.05.001

Guimarães I.P., Brito M.F.L., Lages G.A., Silva Filho A.F., Santos L., Brasilino R.G. 2016. Tonian granitic magmatism of the Borborema Province, NE Brazil: A review. Journal of South American Earth Sciences, 68:97-112. https://doi.org/10.1016/j.jsames.2015.10.009

Harrison T.M. 1982. Diffusion of ${ }^{40} \mathrm{Ar}$ in hornblende. Contributions of Mineralogy and Petrology, 78:324-331. https://doi.org/10.1007/ BF00398927 
Harrison T.M., Duncan I., McDougall I. 1985. Diffusion of ${ }^{40} \mathrm{Ar}$ in biotite: temperature, pressure and compositional effects. Geochimica et Cosmochimica Acta, 49(11):2461-2468. https://doi. org/10.1016/0016-7037(85)90246-7

Hollanda M.H.B.M., Archanjo C.J., Bautista J.R., Souza L.C. 2015. Detrital zircon ages and $\mathrm{Nd}$ isotope compositions of the Seridó and Lavras da Mangabeira basins (Borborema Province, NE Brazil): Evidence for exhumation and recycling associated with a major shift in sedimentary provenance. Precambrian Research, 258:186-207. https://doi. org/10.1016/j.precamres.2014.12.009

Hollanda M.H.B.M., Archanjo C.J., Souza L.C., Dunyi L., Armstrong R. 2011. Long-lived Paleoproterozoic granitic magmatism in the Seridó-Jaguaribe domain, Borborema Province - NE Brazil. Journal of South American Earth Sciences, 32(4):287-300. https://doi.org/10.1016/j.jsames.2011.02.008

Jardim de Sá E.F. 1994. A Faixa Seridó (Província Borborema, NE do Brasil) e o seu significado geodinâmico na cadeia Brasiliana/Pan Africana. Thesis, Universidade de Brasília, Brasília, 803 p.

Klemperer S.L. 2006. Crustal flow in Tibet: geophysical evidence for the physical state of Tibetan lithosphere, and inferred patterns of active flow. In: Law R.D., Searle M.P., Godin L. (Eds.). Channel Flow, Ductile Extrusion and Exhumation in Continental Collision Zones (268, p. 39-70). London: Geological Society of London Special Publication.

Koppers A.A.P. 2002. ArArCALC - sofware for Ar-40/Ar-39 age calculations. Computers and Geosciences, 28(5):605-619. https://doi. org/10.1016/S0098-3004(01)00095-4

Lages G.A., Dantas E.L. 2016. Floresta and Bodocó mafic-ultramafic complexes, Western Borborema Province, Brazil: Geochemical and isotopic constraints for evolution of a Neoproterozoic arc environment and retroeclogitic hosted Ti-mineralization. Precambrian Research, 280:95-119. https://doi.org/10.1016/j.precamres.2016.04.017

Lages G.A., Santos L.C.M.L., Brasilino R.G., Rodrigues J.B., Dantas E.L. 2019. Statherian-Calymmian (ca. $1.6 \mathrm{Ga}$ ) magmatism in the Alto Moxotó Terrane, Borborema Province, Northeast Brazil: Implications for withinplate and coeval collisional tectonics in West Gondwana. Journal of South American Earth Sciences, 91:116-130. https://doi.org/10.1016/j. jsames.2019.02.003

Leloup P.H., Lacassin R., Tapponnier P., Schärer U., Zhong D., Liu X., Zhang L., Shaocheng J., Trinh P.T. 1995. The Ailao Shan-Red River shear zone (Yunnan, China), Tertiary transform boundary of Indochina. Tectonophysics, 251(1-4):13-84.

Lima M.V.A.G., Berrocal J., Soares J.E.P., Fuck R.A. 2015. Deep seismic refraction experiment in Northeast Brazil: New constraints for Borborema province evolution. Journal South American Earth Science, 58:335-349. https://doi.org/10.1016/j.jsames.2014.10.007

Liu J., Chen X., Tang Y., Song Z., Wang W. 2020. The Ailao Shan-Red River shear zone revisited: Timing and tectonic implications. Geological Society of American Bulletin, 132(5-6):1165-1183. https://doi.org/10.1130/B35220.1

Ludwig K.R. 2000. SQUID 1.00. A user manual. Berkeley: Berkeley Geochronology Center, v. 2, 17 p.

Ludwig K.R. 2003. Isoplot 3.00: a geochronological toolkit for Microsoft Excel $^{\circledR}$ (revised version). Berkeley: Berkeley Geochronological Center, v. $4,70 \mathrm{p}$.

Merdith A., Collins A.S., Williams S.E., Pisarevsky S., Foden J.D., Archibald D.B., Blades M.L., Alessio B.L., Armistead S., Plavsa D., Clark C., Muller D. 2017. A full-plate global reconstruction of the Neoproterozoic. Gondwana Research, 50:84-134. https://doi.org/10.1016/j.gr.2017.04.001

Molnar P., Dayem K.E. 2010. Major intracontinental strike-slip faults and contrasts in lithospheric strength. Geosphere, 6(4):444-467. https://doi. org/10.1130/GES00519.1

Monié P., Caby R., Arthaud M.H. 1997. The Neoproterozoic Brasiliano orogeny in Northeast Brazil: ${ }^{40} \mathrm{Ar} /{ }^{39} \mathrm{Ar}$ and petrostructural data from Ceará. Precambrian Research, 81(3-4):241-264. https://doi.org/10.1016/ S0301-9268(96)00037-X

Neves S.P. 2003. Proterozoic history of the Borborema province (NE Brazil): Correlations with neighboring cratons and Pan-African belts and implications for the evolution of Western Gondwana. Tectonics, 22(4):1031. https://doi.org/10.1029/2001TC001352
Neves S.P., Vauchez A., Archanjo C.J. 1996. Shear zone-controlled magma emplacement or magma-assisted nucleation of shear zones? Insights from Northeast Brazil. Tectonophysics, 262(1-4):349-364. https://doi. org/10.1016/0040-1951(96)00007-8

Norris R.J., Toy V.G. 2014. Continental transforms: A view from the Alpine Fault. Journal of Structural Geology, 64:3-31. https://doi.org/10.1016/j. jsg.2014.03.003

Oliveira E.P., Windley B.F., Araújo M.N.C. 2010. The Neoproterozoic Sergipano orogenic belt, NE Brazil: A complete plate tectonic cycle in Western Gondwana. Precambrian Research, 181(1-4):64-84. https://doi. org/10.1016/j.precamres.2010.05.014

Oliveira R.G., Medeiros W.E. 2018. Deep crustal framework of the Borborema Province, NE Brazil, derived from gravity and magnetic data. Precambrian Research, 315:45-65. https://doi.org/10.1016/j.precamres.2018.07.004

Padilha A., Vitorello I., Pádua M.B., Fuck R.A. 2017. Cryptic signatures of Neoproterozoic accretionary events in Northeast Brazil imaged by magnetotellurics: Implications for the assembly of West Gondwana. Tectonophysics, 699:164-167. https://doi.org/10.1016/j.tecto.2017.01.022

Passchier C., Trouw R., Schmitt R.S. 2016. How to make a transverse triple junction - New evidence for the assemblage of Gondwana along the Kaoko-Damara belts, Namibia. Geology, 44(10):843-846. https://doi. org/10.1130/G38015.1

Petronilho L.A. 2009. O método Sm-Nd no CPGeo-IGc-USP: procedimentos analíticos atualmente em rotina. In: Simpósio 45 Anos de Geocronologia no Brasil, Instituto de Geociências, USP. Boletim de Resumos Expandidos, p. 116-118.

Phillips D., Matchan E.L. 2013. Ultra-high precision ${ }^{40} \mathrm{Ar} /{ }^{39} \mathrm{Ar}$ ages for Fish Canyon tuff and Alder Creek rhyolite sanidine: New dating standards required? Geochimica et Cosmochimica Acta, 121:229-239. https://doi. org/10.1016/j.gca.2013.07.003

Pitarello M.Z., Santos T.J.S., Ancelmi M.F. 2019. Syn- to post-depositional processes related to high grade metamorphic BIFs: Geochemical and geochronological evidences from a Paleo to Neoarchean $(3 / 5-2.6 \mathrm{Ga})$ terrane in NE Brazil. Journal of South American Earth Sciences, 96:102312. https://doi.org/10.1016/j.jsames.2019.102312

Rubatto D. 2002. Zircon trace element geochemistry: partitioning with garnet and the link between U-Pb ages and metamorphism. Chemical Geology, 184(1-2):123-138. https://doi.org/10.1016/S0009-2541(01)00355-2

Sá J.M., Bertrand J.M.L, Leterrier J., Macedo M.H.F. 2002. Geochemistry and geochronology of pre-Brasiliano rocks from the Transversal Zone, Borborema Province, Northeast Brazil. Journal of South American Earth Sciences, 14(8):851-866. https://doi.org/10.1016/ S0895-9811(01)00081-5

Sá J.M., McReath I., Leterrier J. 1995. Petrology, geochemistry and geodynamic setting of Proterozoicigneous suites of the Orós belt (Borborema Province, Northeast Brazil). Journal of South American Earth Sciences, 8(3-4):299-314. https://doi.org/10.1016/0895-9811(95)00015-8

Sá J.M., Sousa L.C., Legrand J.M., Galindo A.C., Maia H.N., Filippi R.R. 2014. U-Pb and Sm-Nd data of the Rhyacian and Statherian orthogneisses from Rio Piranhas-Seridó and Jaguaribeano terranes, Borborema Province, Northeast Brazil. Geologia USP. Série Cientifica, 14(3):97-110. https://doi. org/10.5327/Z1519-874X201400030007

Santos E.J., Van Schmus W.R., Kozuch M., Brito Neves B.B. 2010. The Cariris Velhos tectonic event in Northeast Brazil. Journal of South American Earth Sciences, 29(1):61-76. https://doi.org/10.1016/j.jsames.2009.07.003

Santos T.J.S., Fetter A.H., Van Schmus R., Hackspacher P.C. 2009. Evidence for 2.35-2.30 Ga crustal growth in the Northwest Borborema Province, NE Brazil. In: Reddy S.M., Mazunder R., Evan D.A.D., Collins A.S. (Eds.). Paleoproterozoic Supercontinents and Global Evolution (v. 323, p. 271-281). London: Geological Society, Special Publications.

Sato K., Tassinari C.C.G., Basei M.A.S., Siga Jr. O., Onoe A.T., Souza M.D. 2014. Sensitive High-Resolution Ion Microprobe (SHRIMP IIe/MC) of the Institute of Geoscience of the University of São Paulo, Brazil: analytical method and first results. Geologia USP. Série Cientifica, 14(3):3-18. https:// doi.org/10.5327/Z1519-874X201400030001

Sawyer E.W., Cesare B., Brown M. 2011. When the continental crust melts. Elements, 7(4):229-234. https://doi.org/10.2113/gselements.7.4.229 
Scibiorski E., Tohver E., Jourdan F. 2015. Rapid cooling and exhumation in the Western part of the Mesoproterozoic Albany-Fraser Orogen, Western Australia. Precambrian Research, 265:232-248. https://doi.org/10.1016/j. precamres.2015.02.005

Searle M.P., Yeh M.W., Lin T.H., Chung S.L. 2010. Structural constraints on the timing of left-lateral shear along the Red River shear zone in the Ailao Shan and Diancang Shan Ranges, Yunnan, SW China. Geosphere, 6(4):316338. https://doi.org/10.1130/GES00580.1

Sengor A.M.C., Tuysuz O., Imren C., Sakink M., Eyidogan H., Gorur G., Le Pixon X., Ranguin C. 2005. The North Anatolian Fault: a new look. Annual Review of Earth and Planetary Science, 33:37-112. https://doi.org/10.1146/ annurev.earth.32.101802.120415

Silva L.C., McNaughton N.J., Vasconcelos A.M., Gomes J.R.C, Fletcher L.R. 1997. U-Pb SHRIMP ages in the Southern State of Ceará, Borborema Province, NE Brazil: Archean TTG accretion and Proterozoic crustal reworking. In: International Symposium on Granites and Associated Mineralizations, 2., 1997. Annals ..., p. 280-281.

Stacey J.S., Kramers J.D. 1975. Approximation of terrestrial lead isotope evolution by a two-stage model. Earth and Planetary Science Letters, 26(2):207-221. https://doi.org/10.1016/0012-821X(75)90088-6

Tapponnier P., Peltzer G., Le Dain A.Y., Armijo R., Cobbold P. 1982. Propagating extrusion tectonic in Asia: New insights from simple experiments with plasticine. Geology, 10(12):611-616. https://doi. org/10.1130/0091-7613(1982)10\%3C611:PETIAN\%3E2.0.CO;2

Tommasi A., Vauchez A., Daudré B. 1995. Initiation and propagation of shear zones in a heterogeneous continental lithosphere. Journal of Geophysical Research, 100(B11):22083-22101. https://doi.org/10.1029/95JB02042

Tohver E., Trindade R.I.F., Solum J.G., Hall C.M., Riccomini C., Nogueira A.C. 2010. Closing the Clymene Ocean and bending a Brasiliano belt: evidence for the Cambrian formation of Gondwana, Southeast Amazon craton. Geology, 38(3):267-270. https://doi.org/10.1130/G30510.1
Van Schmus W.R., Brito Neves B.B., Williams I.S., Hackspacher P.C., Fetter A.H., Dantas E.L., Babinski M. 2003. The Seridó Group of NE Brazil, a late Neoproterozoic pre- to syn-collisional basin in the West Gondwana: insights from SHRIMP U-Pb detrital zircon ages and $\mathrm{Sm}-\mathrm{Nd}$ crustal residence $\left(\mathrm{T}_{\mathrm{DM}}\right)$ ages. Precambrian Research, 127(4):287-327. https://doi. org/10.1016/S0301-9268(03)00197-9

Vauchez A., Egydio da Silva M. 1992. Termination of a continentalscale strike-slip fault in partially melted crust: The West-Pernambuco shear zone, Northeast Brazil. Geology, 20(11):1007-1010. https://doi. org/10.1130/0091-7613(1992)020\%3C1007:TOACSS\%3E2.3.CO;2

Vauchez A., Tommasi A. 2003. Wrench faults down to the asthenosphere: geological and geophysical evidence and thermomechanical effects. Geological Society, London, Special Publications, 210(1):15-34. https://doi. org/10.1144/GSL.SP.2003.210.01.02

Viegas L.G.F., Archanjo C.J., Hollanda M.H.B.M., Vauchez A. 2014. Microfabrics and zircon U-Pb (SHRIMP) chronology of mylonites from the Patos shear zone (Borborema Province, NE Brazil). Precambrian Research, 243:1-17. https://doi.org/10.1016/j.precamres.2013.12.020

Viegas L.G.F., Archanjo C.J., Vauchez A. 2013. Fabrics of migmatites and the relationships between partial melting and deformation in high-grade transpressional shear zones: The Espinho Branco anatexite (Borborema Province, NE Brazil). Journal of Structural Geology, 48:45-56. https://doi. org/10.1016/j.jsg.2012.12.008

Weinberg R., Sial A.N., Mariano G. 2004. Close spatial relationship between plutons and shear zones. Geology, 32(5):377-380. https://doi. org/10.1130/G20290.1

Willigers B.J.A, Van Gool J.A.M., Wijbrans J.R., Krogstad E.J., Mezger K. 2002. Post-tectonic cooling of the Nagssugtoqidian Orogen and a comparison of contrasting cooling histories in Precambrian and Phanerozoic orogens. Journal of Geology, 110(5):503-517. https://doi.org/10.1086/341595

Woodcock N.H., Schubert C. 1994. Continental strike-slip tectonics. In: Hancock P.L. (ed.). Continental Tectonics (p. 251-263). Oxford: Pergamon Press. 